\title{
Growth in the brown shrimp Crangon crangon. II. Meta-analysis and modelling
}

\author{
Marc Hufnagl ${ }^{*}$, Axel Temming \\ Institute for Hydrobiology and Fishery Science, Olbersweg 24, 22767 Hamburg, Germany
}

\begin{abstract}
Existing laboratory and field data on growth were combined, reanalyzed and discussed to generate a holistic temperature-, length- and gender-dependent growth rate $\left(G, \mathrm{~mm} \mathrm{~d}^{-1}\right)$ model for North Sea region brown shrimp Crangon crangon (L.). Length $(L, \mathrm{~mm})$ and temperature $\left(T,{ }^{\circ} \mathrm{C}\right)$ dependent growth rates of Crangon crangon are highly variable within and among studies but decrease with $L$ and increase with $T$. Applying general nonlinear regression, mean growth was derived as $G=0.02421 \cdot T-0.00115 \cdot e^{0.08492 \cdot T} \cdot L\left(\mathrm{r}^{2}=0.860\right)$. Applying quantile regression $(75$ th percentile), a growth model describing growth of the fastest growing fraction of the population was derived as $G_{\max }=0.03054 \cdot T-0.00104 \cdot \mathrm{e}^{0.09984 \cdot T} \cdot L\left(\mathrm{r}^{2}=0.857\right)$. Female growth rates were higher than male growth rates and were similar to $G_{\max }$. In a simulation, $G$ and $G_{\max }$ were used with seasonally varying temperature to generate monthly length trajectories (cohorts). Further, length-based mortality was included and the fraction of each cohort attaining minimal commercial size was calculated. May cohorts (5 mm initial length), representing spring recruitment, grew to $50 \mathrm{~mm}$ by November if $G$ was used. Application of the fast growth model $\left(G_{\max }\right)$ allowed for the same length to be reached $2 \mathrm{mo}$ earlier. We conclude that the autumnal peak in adult abundance in the North Sea is most probably due to recruitment from the spring cohort of the same year. Our results suggest that the previous year's summer cohort contributes little to this autumnal peak because of high cumulative and overwintering mortality.
\end{abstract}

KEY WORDS: Growth rates $\cdot$ Life cycle $\cdot$ Recruitment $\cdot$ Commercial fishing $\cdot$ Size-at-age $\cdot$ Moult Resale or republication not permitted without written consent of the publisher

\section{INTRODUCTION}

The breeding season of the common brown shrimp Crangon crangon (L.) (Caridea: Decapoda) extends throughout the year along the Dutch and German coasts (Kuipers \& Dapper 1984), with the highest and lowest numbers of egg-bearing shrimps being observed from February to July and September through October, respectively (Neudecker \& Damm 1992, Siegel et al. 2008).

Eggs can be classified into summer (April to September) and winter eggs (October to March; Havinga 1930). Egg types differ according to size, dry mass, carbon content (Paschke et al. 2004) and larval hatch size (Boddeke 1982), with values in all cases being lower for summer eggs. Additionally, intermoult periods are shorter and number of gravid females are higher during summer, increasing the number of summer eggs in relation to winter eggs (Temming \& Damm 2002).
Crangon crangon passes through up to 6 different planktonic zoeal stages that end in a benthic stage of $\sim 5 \mathrm{~mm}$ total length $(L)$ (Gurney 1982, Criales \& Anger 1986). Highest abundances of postlarval/early juvenile C. crangon are observed on the flats and intertidal areas in late spring and early summer (May to June). At this stage, the $L$ of juveniles is $\sim 7-20 \mathrm{~mm}$ (Beukema 1992, Temming \& Damm 2002).

The abundance of adult shrimps is highest during September and October (Maes et al. 1998, Henderson et al. 2006), corresponding with a peak in commercial catches (ICES 2010). The latter, if standardized for effort, can be used as an index of adult abundance, as catches are landed throughout the year. Commerical beam trawls retain shrimps $>45 \mathrm{~mm}$ and landings are sieved to a minimum size of $\sim 50 \mathrm{~mm}$. Since females grow larger than males (Tiews 1970, Hufnagl et al. 2010a), the majority of the commercially exploited 
shrimps (>50 mm) are adult females (Tiews 1954, Martens \& Redant 1986).

While Temming \& Damm (2002) have shown that the spring recruitment most likely originates from the winter egg production of the previous winter, it is still not clear whether this spring recruitment generates the autumn peak of adult density. This uncertainty mainly originates from differences in reported growth rates from both laboratory and field studies. The different hypotheses assign the autumn peak in adult density either to shrimps from the same year's spring recruitment (Kuipers \& Dapper 1984), the same year's summer recruitment (Boddeke \& Becker 1979) or the previous year's summer recruitment (Campos et al. 2009a).

Boddeke \& Becker's (1979) hypothesis obviously requires the highest growth rates followed by the life cycle model of Kuipers \& Dapper (1984). The latter concept was based on laboratory growth data obtained by $\mathrm{M}$. Fonds (unpubl.), but these rates were too low to connect the maximum juvenile abundance in spring with the maximum landings per unit effort (LPUE) in autumn, as discussed by Beukema (1992). Berghahn (1991) calculated that higher temperatures experienced by juveniles dwelling in tidal pools would allow for higher growth, which might close this gap. However, the data obtained by M. Fonds were not separated by gender, and will therefore likely underestimate the most relevant female growth. Finally, based on new growth experiments and results of a dynamic energy budget model (DEB), Campos et al. (2009a) suggested that $>1 \mathrm{yr}$ is needed to reach adult size. Their study shifts the important egg production period towards the previous years' summer.

Growth estimates in shrimp are difficult to obtain because no reliable aging method exists (Hartnoll 2001). Thus, growth information only originates from either laboratory observations, or field studies following the progression of length modes. Growth rates of Crangon crangon are highly variable not only within, but also among studies. Reported rates of $20-30 \mathrm{~mm}$ shrimps at $20^{\circ} \mathrm{C}$ varied from around $0 \mathrm{~mm} \mathrm{~d}^{-1}$ (Edwards 1978), to $>0.2 \mathrm{~mm} \mathrm{~d}^{-1}$ (van Lissa 1977), to $0.5 \mathrm{~mm} \mathrm{~d}^{-1}$ (Dalley 1980) (see also Fig. 1).

In a previous study, Hufnagl \& Temming (2011, this volume) determined growth rates of $20-60 \mathrm{~mm}$ shrimps at 5 to $25^{\circ} \mathrm{C}$ and observed that not only temperature and $L$, but also gender and catch date, significantly influenced growth. Female shrimps grew faster than male shrimps. Shrimps from the earlier catch (May) grew slower than shrimps from the later July sampling. Hufnagl \& Temming (2011) assumed that shrimps from the earlier catch were older overwintering individuals (although of similar length) than shrimps collected later, as the first recruitment peak of juvenile shrimps occurred after the May sampling. The growth performances of the 2 groups (collected at different dates) were significantly different, with growth rates being lower for the most likely older, but comparably sized shrimps. For the faster growing, younger group, distinct gender- and temperature-specific growth patterns were observed. Due to this unexpected cohort effect, however, a large part of the study revealed only suboptimal growth rates and the data representing optimal growth remained incomplete with regard to the coverage of size, gender and temperature. Many earlier studies suffer from similar problems due to either suboptimal growth in part of the experiments, or a focus on only a few size classes or temperatures as in the case of field studies tracking cohorts.

This brought us to the idea of combining all these data sources to allow the parameterization of a full growth model based on a combined, literature based, meta data set. Since mortality in Crangon crangon is known to be very high (Tiews \& Schumacher 1982, del Norte-Campos \& Temming 1998, Hufnagl et al. 2010b), one focus of the growth model should be on maximum growth. The idea was that slowly growing individuals will not contribute substantially to the adult population because of high cumulative mortality during a prolonged period of growth to adult size. Analysis was attempted in 2 ways: (1) analyzing gender-specific data and taking mean female growth as a proxy for fast growth, and (2) conducting percentile regression to describe the 75th percentile instead of the mean growth. The first approach is based on observations by Meixner (1969), Campos et al. (2009b), and Hufnagl \& Temming (2011) showing that female growth is significantly faster than male growth. The justification for the second approach is that all studies can be included, but the effect of males and poorly growing shrimp fed with inadequate prey sources can be eliminated.

If the likely growth rates of the relevant parts of the population, i.e. fast growing individuals, can successfully be described from such an analysis, it should also be possible to determine the most likely life cycle scenario. For this purpose, the growth trajectories of the different season cohorts can be calculated in combination with ambient seasonal temperature data. The clarification of the life cycle has an applied aspect, because there is a tendency to increase boat sizes and extend fishing operations during winter (Salz \& de Wilde 1990, Berghahn 1991). If the Kuipers \& Dapper (1984) version of the life cycle would be confirmed, such an intensified winter fishery should be monitored for any potential negative effects on recruitment.

The specific objectives of this study are therefore to (1) combine and analyze published temperature-, gender- and length-dependent growth data, (2) develop and parameterize comprehensive models of mean and 
maximum growth with size, temperature and gender as explanatory variables, (3) analyze whether specific methods (field vs. laboratory) or treatments cause bias in the growth data set, and (4) describe the growth trajectories of different season cohorts in combination with seasonal ambient temperatures and mortality estimates to clarify the life cycle of Crangon crangon in the North Sea.

\section{MATERIALS AND METHODS}

In total, 36 studies containing growth and/or moult information on Crangon crangon were accessed (Table 1, see Fig. 1). The focus of this study is on the greater North Sea region between $5^{\circ} \mathrm{W}, 14^{\circ} \mathrm{E}$, and $48^{\circ}$ and $60^{\circ} \mathrm{N}$. Twenty-five different growth studies were performed in this region. No genetic differences were observed for the North Sea (Luttikhuizen et al. 2008) and the population can be regarded as genetically mixed based on general ocean circulation patterns in combination with extended larval drift periods. Some studies were performed outside this defined North Sea region, e.g. in the Baltic (Dornheim 1969), in the Mediterranean Sea (Labat 1977), off Portugal (Viegas et al. 2007, Campos et al. 2009b), and in the Bay of Biscay (Lagadère 1982). These studies are also listed in Table 1 but were not used to parameterize the growth model. Besides regional separation from the North Sea, Baltic Sea brown shrimp also permanently experience salinities $<16$ and the effect of this low salinity on metabolism and growth is unclear. Three studies contained only information on moult increment or on intermoult period but not on growth rates (Lloyd \& Yonge 1947, Regnault 1979, Schatte \& Saborowski 2005).

In 2 cases (Oh et al. 1999, Oh \& Hartnoll 2000), carapace length was converted to $L$ using a relationship stated in the article. In 2 other cases (Schockaert 1968, Henderson \& Holmes 1987), growth rates were extracted from graphs using a MATLAB routine. For the conversion of wet weight growth (Edwards 1978) into length growth, the $L$-wet weight $(w W)$ relationship

$$
W W=4.0625 \times 10^{-6} \cdot L^{3.084}
$$

was used ( $n=8305, r^{2}=0.985$; Hufnagl et al. 2010a).

From studies on toxic or stress effects, only control groups were used in our analysis (Edwards 1978, Oh \& Hartnoll 2000). Data from Gerlach \& Schrage (1969) were not included in the growth model parameterization as temperature was uncontrolled and varied between 5 and $25^{\circ} \mathrm{C}$ in their experiments.

Growth rates determined for larval Crangon crangon (Criales \& Anger 1986, Cattrijsse et al. 1997) were added to complete the review but values were also not used in the growth model as only juvenile and adult growth is examined in our study. Growth of larvae is often not isometric, but this is one requirement of the von Bertalanffy growth model used in the actual study. Finally, the laboratory data presented in Hufnagl \& Temming (2011) were added to the data set.

Growth function. The von Bertalanffy growth curve describes growth as the net effect of anabolism (Eq. 2, left term) minus catabolism (Eq. 2, right term)

$$
\frac{\mathrm{d} W}{\mathrm{~d} t}=H \cdot W^{\frac{2}{3}}-k \cdot W
$$

where $W=$ weight, $k$ = catabolic constant, equivalent to \% weight loss per unit time in starving individuals, and $H=$ anabolic constant, which is related to food intake and synthesis of body mass. Transformation of Eq. (2) to length growth $\left(W \approx L^{3}\right)$ leads to

$$
\frac{\mathrm{d} L}{\mathrm{~d} t}=E-K \cdot L
$$

where $L=$ total length, $K=\mathrm{k} / 3$, and $E$ represents anabolism. Eq. (3) was expanded by Kuipers \& Dapper (1981) with temperature $(T)$ as an additional variable influencing $E$ :

$$
\frac{\mathrm{d} L}{\mathrm{~d} t}=a+b \cdot T-K \cdot L
$$

where $a$ and $b$ are constants. In this equation, $K \cdot L$ represents length dependent metabolism. However, metabolism generally increases exponentially with $T$. An exponential temperature term was therefore included into Eq. (4), replacing $K$ with $C \cdot \mathrm{e}^{d \cdot T}$ :

$$
\frac{\mathrm{d} L}{\mathrm{~d} t}=a+b \cdot T-c \cdot \mathrm{e}^{d \cdot T} \cdot L
$$

where $c$ and $d$ are additional constants. Asymptotic length $\left(L_{\infty}\right)$ can be calculated from Eq. (5) as the length where growth is zero, i.e. $\mathrm{d} L / \mathrm{d} t=0$ :

$$
L_{\infty}=\frac{a+b \cdot T}{c \cdot \mathrm{e}^{d \cdot T}}
$$

This equation shows that $L_{\infty}$ is inversely related to $K=c \cdot \mathrm{e}^{d \cdot T}$ and directly proportional to anabolism. As the exponential term increases faster than the linear term, it can be deduced that from this formulation, $L_{\infty}$ decreases with increasing temperature.

Sensitivity of growth estimates to the inclusion of specific studies or methods. Specific data sets or methods could theoretically generate bias or variability in a model based on the whole data set. Field studies might for example systematically underestimate growth rates due to length dependent emigration or predation. Laboratory studies might underestimate growth due to poor food quality or stress. To test for a general effect of a method (field/laboratory), the data set was split according to the method used and the growth model (Eq. 5) was fitted independently to each subset.

Potential bias introduced by single studies was tested: of the whole North Sea data set made up of 25 studies, 1 to 4 randomly chosen studies were excluded from the data set and parameters a to $d$ and their $95 \%$ 


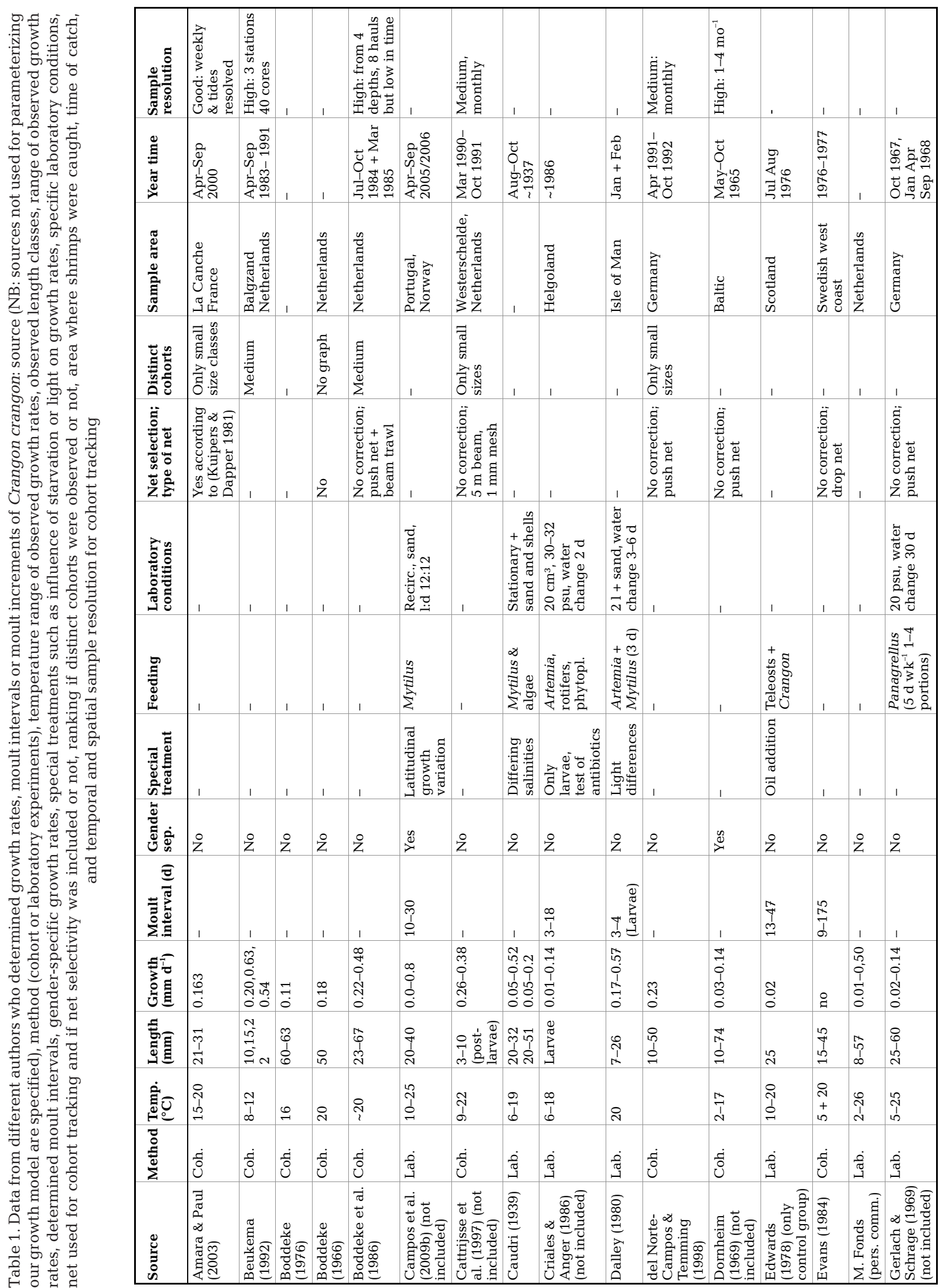




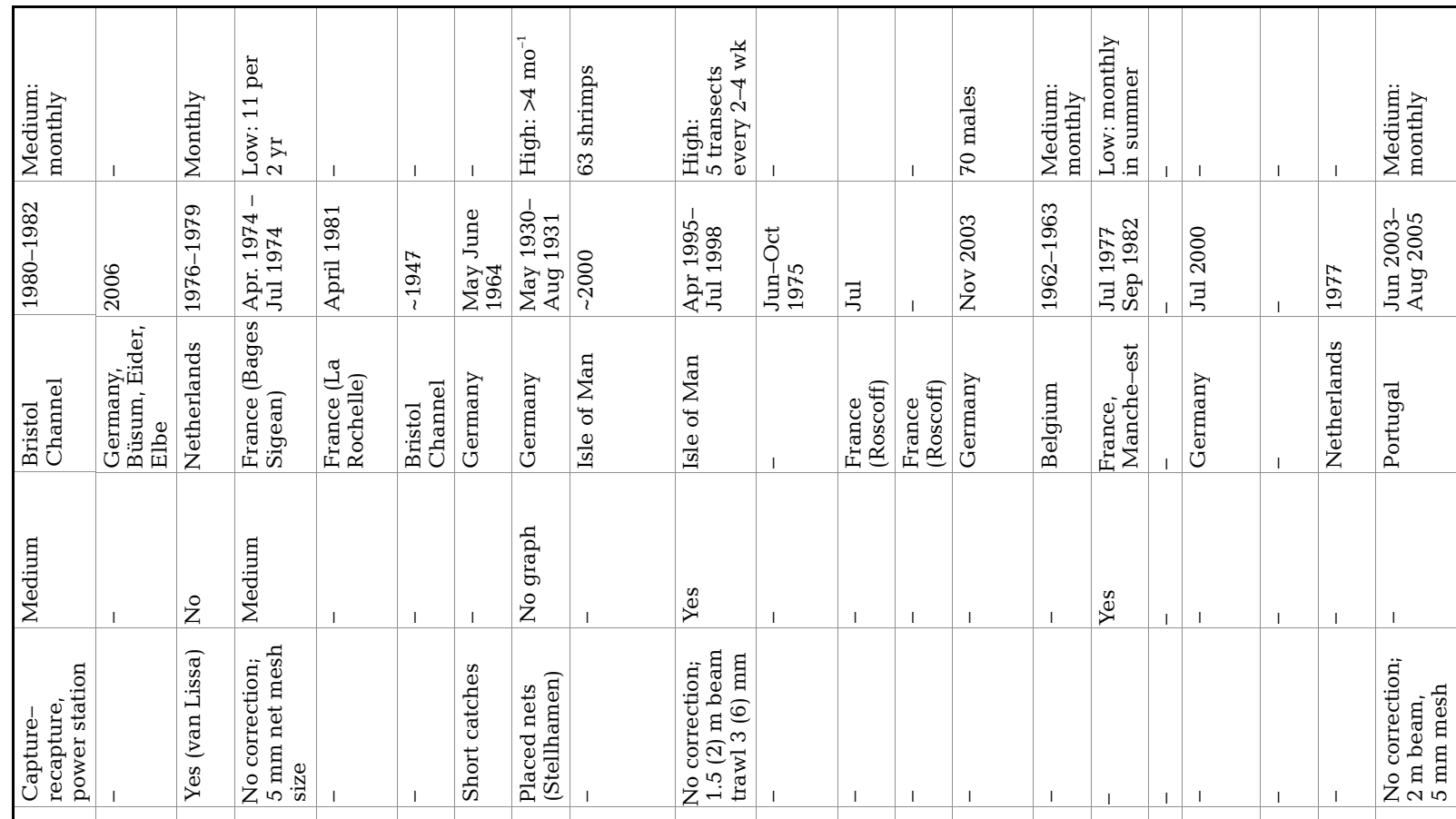

\begin{tabular}{|c|c|c|c|c|c|c|c|c|c|c|c|c|c|c|c|c|c|c|c|c|}
\hline 1 & 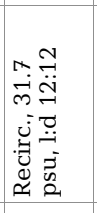 & 1 & 1 & 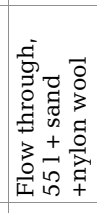 & 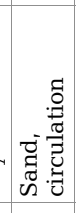 & 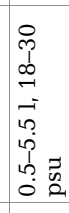 & , & 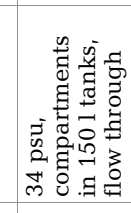 & & 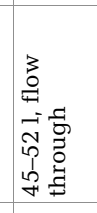 & 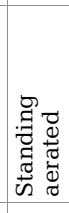 & & 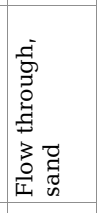 & 1 & 1 & & 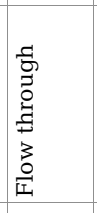 & 1 & 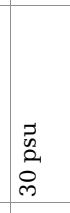 & 1 \\
\hline I & 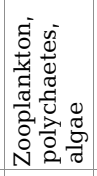 & , & 1 & 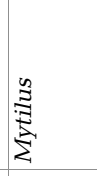 & 商 & 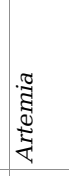 & । & 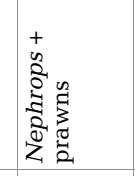 & & 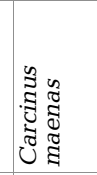 & 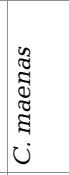 & 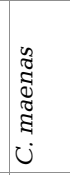 & 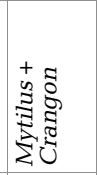 & 1 & 1 & & 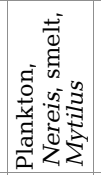 & , & 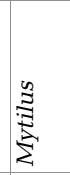 & \\
\hline 1 & 童 & 1 & 1 & 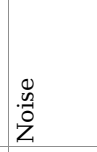 & 1 & & 1 & 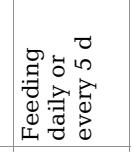 & & 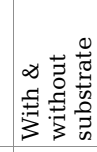 & $\begin{array}{l}0 \\
\overrightarrow{0} \\
0 \\
0 \\
0 \\
\vdots \\
\Sigma\end{array}$ & 悹 & 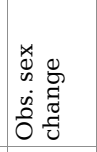 & 1 & 1 & 1 & 1 & 1 & 1 & 1 \\
\hline Z̊ & $\underset{\nu}{\mathscr{\nu}}$ & ż & $\underset{\nearrow}{\mathscr{\swarrow}}$ & $\overbrace{\nu}^{\swarrow}$ & 1 & 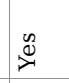 & z̊ & Ż & 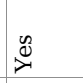 & そ̊ & z & ż & $\frac{\substack{\tilde{J} \\
\Sigma}}{\Sigma}$ & $\stackrel{2}{ }$ & ż & \& & $\underset{\nu}{\breve{\nu}}$ & ż & z̊ & ż \\
\hline 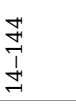 & $\begin{array}{l}0 \\
\vdots \\
\infty\end{array}$ & 1 & 1 & 1 & 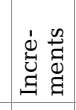 & $\underset{I}{\stackrel{I}{I}}$ & & $\begin{array}{l}0 \\
0 \\
0 \\
0\end{array}$ & 1 & 1 & $\because$ & & 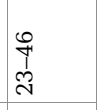 & 1 & 1 & & $\begin{array}{l}\overrightarrow{1} \\
\vec{w} \\
\vec{q}\end{array}$ & 1 & 1 & 1 \\
\hline $\begin{array}{l}0 \\
? \\
0 \\
0 \\
0 \\
0 \\
0\end{array}$ & $\begin{array}{l}\infty \\
0 \\
0 \\
0 \\
0 \\
0\end{array}$ & $\begin{array}{l}\infty \\
0 \\
0 \\
1 \\
7 \\
0 \\
0\end{array}$ & $\begin{array}{l}\infty \\
0 \\
0 \\
0 \\
0 \\
0 \\
0 \\
0\end{array}$ & 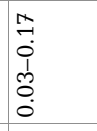 & 1 & $\begin{array}{l}0 \\
0 \\
0 \\
0 \\
0 \\
0 \\
0\end{array}$ & $\begin{array}{l}\text { İ } \\
0 \\
0 \\
0 \\
0 \\
0\end{array}$ & $\begin{array}{l}\stackrel{0}{0} \\
0 \\
0 \\
0 \\
0\end{array}$ & $\begin{array}{l}7 \\
0 \\
0 \\
0 \\
0 \\
0\end{array}$ & 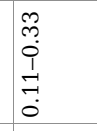 & ż & సู & ż & $\begin{array}{l}\text { Na } \\
0 \\
0 \\
0 \\
0 \\
0\end{array}$ & $\begin{array}{l}0 \\
9 \\
0 \\
1 \\
0 \\
0 \\
0\end{array}$ & & 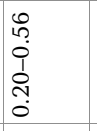 & $\stackrel{m}{\longrightarrow}$ & $\begin{array}{l}\text { N } \\
0 \\
0 \\
0 \\
0 \\
0\end{array}$ & $\stackrel{\leftrightarrow}{\tilde{m}}$ \\
\hline $\begin{array}{l}0 \\
\vdots \\
\vdots \\
ల \\
m\end{array}$ & 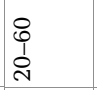 & $\begin{array}{l}0 \\
\tilde{n} \\
n \\
\end{array}$ & $\begin{array}{l}0 \\
11 \\
\infty\end{array}$ & $\begin{array}{l}\tilde{W} \\
\text { D్ల } \\
\text { m }\end{array}$ & 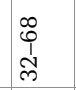 & 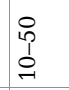 & $\begin{array}{l}\infty \\
0 \\
n \\
\sim \\
\sim\end{array}$ & $\begin{array}{l}n \\
y \\
4 \\
m\end{array}$ & $\begin{array}{l}\overrightarrow{0} \\
\stackrel{j}{d}\end{array}$ & $\begin{array}{l}\text { \& } \\
\text { I }\end{array}$ & ก & i & $\begin{array}{l}\text { లి } \\
\text { d్ }\end{array}$ & \begin{tabular}{l}
$n$ \\
$\vdots$ \\
1 \\
\hdashline
\end{tabular} & $\begin{array}{l}\overrightarrow{0} \\
\vdots \\
\mathbb{N}\end{array}$ & & $\begin{array}{l}\text { İ } \\
\text { d. }\end{array}$ & $\begin{array}{l}\vec{p} \\
\tilde{q} \\
q\end{array}$ & $\begin{array}{l}\forall \\
\stackrel{H}{*}\end{array}$ & $\begin{array}{l}\breve{b} \\
i n\end{array}$ \\
\hline 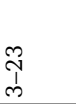 & $\begin{array}{l}\text { స్ } \\
\text { చ } \\
\omega\end{array}$ & $\frac{9}{\overrightarrow{1}}$ & $\begin{array}{l}\stackrel{i}{T} \\
\stackrel{d}{\sim}\end{array}$ & $\begin{array}{l}\widetilde{N} \\
\omega \\
\sim \\
-1\end{array}$ & $\cong$ & $\nexists$ & $\begin{array}{l}\text { ì } \\
\text { in }\end{array}$ & $\stackrel{2}{\sim}$ & 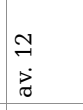 & $\begin{array}{l}\stackrel{9}{1} \\
\stackrel{5}{\rightarrow}\end{array}$ & $\stackrel{g}{\rightarrow}$ & $\begin{array}{l}\stackrel{J}{I} \\
\text { I }\end{array}$ & $\begin{array}{l}0 \\
\text { 1 } \\
i n\end{array}$ & 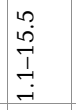 & $\begin{array}{l}\infty \\
\vec{b} \\
\underline{-1}\end{array}$ & & $\stackrel{n}{a}$ & $\underset{ت}{\sharp}$ & 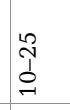 & 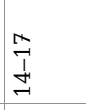 \\
\hline : & 家 & ป் & हं & 完 & 寄 & 察 & نं & 曾 & ن & 审 & 家 & 迥 & 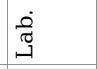 & i̊ & dं & & 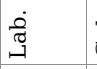 & ச் & 完 & ક̊ં \\
\hline 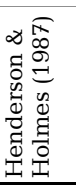 & 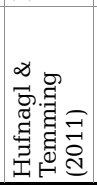 & 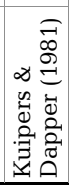 & 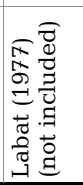 & 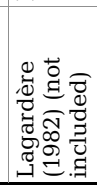 & 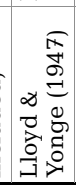 & 苍 & 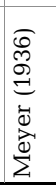 & 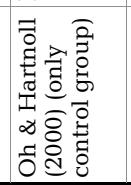 & 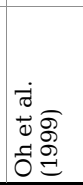 & 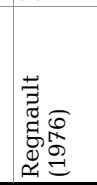 & 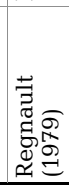 & 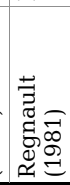 & 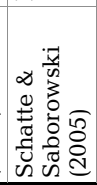 & 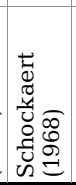 & 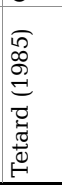 & 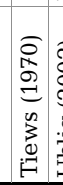 & 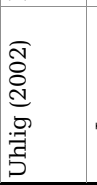 & 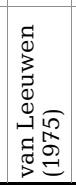 & 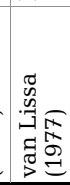 & 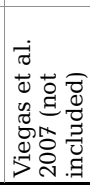 \\
\hline
\end{tabular}


confidence limits for a fit with Eq. (5) were estimated.

Model fitting to subsets of data. Growth models were determined based on all 25 North Sea studies. Both growth models (Eq. 4, no T-L interaction; and Eq. 5, with 2 temperature terms) were fitted to the data, applying nonlinear regression using the statistical program SPSS. The quality of the fit was evaluated using the $\mathrm{r}^{2}$, the $95 \%$ CIs of the parameters, and significance levels ( $p$ ) of whether a parameter is significantly different from zero.

We combined all growth rates in $10 \mathrm{~mm}$ $L(20, \ldots, 80 \mathrm{~mm})$ and $5^{\circ} \mathrm{C} \mathrm{T}\left(5, \ldots, 25^{\circ} \mathrm{C}\right)$ classes (Table 2). Fast growth $\left(G_{\max }\right)$, here defined as the growth rate of the fraction of the population growing at rates between the median and maximum observed growth rate, was calculated based on these $T-L$ groups. $G_{\max }$ was estimated by quantile regression (Koenker \& Bassett 1978) based on the 75th percentiles. In an alternative analysis, the growth model (Eq. 5) was fitted to the mean growth rate (of each $T-L$ group) $+1 \mathrm{SD}$.

Based on Eqs. (4), (5) \& (6), annual von Bertalanffy growth parameters $K$ and $L_{\infty}$ were calculated assuming a mean North Sea temperature of $10^{\circ} \mathrm{C}$ (Eq. 7). In addition, the growth performance index $\Phi^{\prime}=$ $\log (K)+2 \log \left(L_{\infty}\right)$ (Munro \& Pauly 1983) was calculated to allow comparison of data with those of other species.

Only 7 studies separated growth rates according to gender and 3 of them were not from the greater North Sea region (Labat 1977, Lagardère 1982, Campos et al. $2009 b)$. The number of gender-specific growth observations was too low to estimate all parameters of Eq. (5). Thus, the influence of gender on growth was tested by linear regression of male (dependent variable) and female (independent variable) growth rates reported for similar $T$ and $L$ classes.

Further, Eq. (5) with a fixed parameter $d$ was fitted to male and female growth rates from North Sea studies that separated gender (Meixner 1969, Oh et al. 1999, Uhlig 2002, Hufnagl \& Temming 2011 this volume), assuming that the temperature dependence of metabolism is not gender-specific. Parameter $d$ was taken from the $G_{\text {mean }}$ model and was therefore based on all 25 studies.

Application of the growth model to field temperature data. In this exercise, egg and larval development was not considered. Therefore, an initial $L$ of $5 \mathrm{~mm}$ was chosen, representing youngest postlarval shrimp length (Criales \& Anger 1986). Eq. (5) was used in com- bination with daily field temperature data, to calculate growth in the field. This was done in a stepwise fashion, starting with $5 \mathrm{~mm}$ total length and adding to each daily step the growth increment (Eq. 5) calculated with the corresponding temperature (Eq. 7). The new length $\left(L_{\text {new }}=L_{\text {old }}+G\right)$ for each day was then used for each subsequent iteration. Negative growth rates were set to zero in the calculation to avoid shrinking. For each start of a month, one cohort of animals was started with $5 \mathrm{~mm}$ length, and length trajectories were generated.

Daily temperatures were derived from temperature data measured in Büsum harbor, as a Wadden Sea point, and at the Weser light ship, as a near shore but open water point, applying the data presented by Temming \& Damm (2002). The 2 geographical points were chosen as Crangon crangon dwell close to the shore but avoid low winter temperatures by migrating to deeper water (Boddeke et al. 1976, Pihl \& Rosenberg 1982, Berghahn 1983). From each data series, the warmer of the 2 daily temperatures was chosen, to construct one temperature data set of likely temperatures experienced by C. crangon. This data set can be described by a sine function: 


$$
T_{i}=9.8933+7.3877 \cdot \sin [0.01756 \cdot(i-131.1761)]
$$

where $T_{i}=$ temperature at Day $i$ and $i \in 1$ to 365 .

Initial cohort size was set to 100 and a fraction of this cohort died each day. For adult shrimps $>45 \mathrm{~mm}$, an annual total exponential mortality rate of $Z=5.3 \mathrm{yr}^{-1}$ was used to calculate the cohort size at the following day $\left(N_{i+1}\right)$ based upon the present cohort size $\left(N_{i}\right): N_{i+1}$ $=N_{i} \mathrm{e}^{-Z / 365}$. This $Z$ value represents the long term median (1956 to 2006) for adult North Sea brown shrimps (Hufnagl et al. 2010b). Mortality was applied daily, converting the annual rate into a daily rate by division with 365. Smaller shrimps most likely experience higher mortalities due to higher numbers of potential predators. Juvenile mortality can be up to $4 \times$ higher than the value determined for adult shrimps (del Norte-Campos \& Temming 1998). The size effect on mortality was included into our calculations and $Z$ for each size class $<45 \mathrm{~mm}$ was determined according to Peterson \& Wroblewski (1984). For example, a 15, 20 or $30 \mathrm{~mm}$ shrimp experiences a $Z$ of $16.3,14.4$ or 10.6 $\mathrm{yr}^{-1}$, respectively. This estimate is conservative in comparison to reported field measurements ( $Z$ up to $22 \mathrm{yr}^{-1}$; del Norte-Campos \& Temming 1998). Annual rates were again converted to daily rates by division with 365.

Moult interval and increment. Several studies reported data on moult intervals (intermoult periods) of brown shrimps (Table 1). In combination with data determined by Hufnagl \& Temming (2011), a lengthand temperature-dependent moult interval (MI) model was parameterized:

$$
\mathrm{MI}=a_{\mathrm{MI}} \cdot T L^{b_{\mathrm{MI}}} \cdot \mathrm{e}^{c_{\mathrm{MI}} T}
$$

where $a_{\mathrm{MI}}, b_{\mathrm{MI}}$ and $c_{\mathrm{MI}}$ are constants. Hufnagl \& Temming (2011) found growth variability to be mainly determined by variable moult increments, whereas moult intervals were less variable at a given $T$ and $L$.

Only a few authors (Table 1 ) reported data on moult increments. Fitting a $T$ and $L$ dependent function to these data was not possible. Maximum expected moult increments were therefore calculated as the product of the growth rate (Eq. 5, with the parameters for maximum growth) and the moult interval estimated using Eq. (8). Calculated values were compared to observed rates.

\section{RESULTS}

Crangon crangon growth was determined by modal progression analysis in 14 field studies, and through laboratory experiments in 11 studies (Table 1); 5 articles only reported moult intervals or increments, and 5 were performed outside the North Sea.
Most published studies examined growth rates at temperatures between 10 and $20^{\circ} \mathrm{C}$. Growth variability was high both between and within studies (Fig. 1). At $15^{\circ} \mathrm{C}$, growth rates varied between 0 and $0.6 \mathrm{~mm} \mathrm{~d}^{-1}$ or between 0 and $0.7 \mathrm{~mm} \mathrm{~d}^{-1}$ at $20^{\circ} \mathrm{C}$ (interstudy variability). Some authors (e.g. Schockaert 1968, Dalley 1980, Kuipers \& Dapper 1981) observed growth rates in their studies that differed by $>0.2 \mathrm{~mm} \mathrm{~d}^{-1}$ within one $T-L$ class (intrastudy variability). Highest mean growth rates of $0.57 \mathrm{~mm} \mathrm{~d}^{-1}$ were observed by Dalley (1980) at $20^{\circ} \mathrm{C}$ for a group of animals growing from $16.45 \mathrm{~mm}$ (mean) to $22.18 \mathrm{~mm}$ (mean) within $10 \mathrm{~d}$ (Fig. 1). Similarly, Uhlig (2002) observed mean growth rates of 0.52 (male) and $0.56 \mathrm{~mm} \mathrm{~d}^{-1}$ (female) for a group of $20 \mathrm{~mm}$ shrimps reared at field temperatures between 15.9 and $17.1^{\circ} \mathrm{C}$.

Growth rates were maximum for Crangon crangon between 20 and $30 \mathrm{~mm}$ (Fig. 1) and decreased slightly towards the $10 \mathrm{~mm}$ class. With increasing size (>20 mm), growth rates decreased steadily. The length effect on growth rate increased with increasing temperature, and was less pronounced at low temperatures. Maximum growth rates at 10 to $25^{\circ} \mathrm{C}$ were $\sim 6 \times$ higher than those observed at $5^{\circ} \mathrm{C}$.

Growth rates for shrimps <10 mm (Fig. 1; Criales \& Anger 1986, Dalley 1981) were $<0.15 \mathrm{~mm} \mathrm{~d}^{-1}$ and less than the rates determined for $20 \mathrm{~mm}$ shrimps.

Splitting the data set into field studies and laboratory experiments did not indicate any differences with regard to either mean growth rates or growth variance, and parameter estimates were within the confidence limits of $G$ in all cases (results not shown, but see Fig. 2 for comparison).

Parameter estimates were also not significantly influenced by single studies (Fig. 2) or by the exclusion of specific studies plus 1 to 3 additional randomly chosen studies. If single studies were omitted, the parameter estimates always remained within the $95 \%$ CIs of parameter estimates based on the whole data set $(G)$. Maximum influence $(10 \%$ deviation) on parameter $b$, which determines the temperature-dependent offset of the growth model, was observed if data from Hufnagl \& Temming (2011) were excluded. Exclusion of growth rates determined by van Lissa (1977) and Tetard (1985) increased parameter $C$ (which determines lengthdependent growth) by 17 and $27 \%$, whereas exclusion of Schockaert (1968), Oh et al. (1999) and M. Fonds (pers. comm.) decreased parameter $C$ by 16, 21 and $15 \%$, respectively. Exclusion of the latter 2 data sets increased parameter $d$ ( $T$ effect on growth $\propto Q_{10}$ ) by 12 and $14 \%$, respectively. Exclusion of the data of van Lissa (1977) and Tetard (1985) decreased parameter $d$ by 11 and $10 \%$, respectively. Parameter a was not significantly different from zero, regardless of which data set was excluded. 


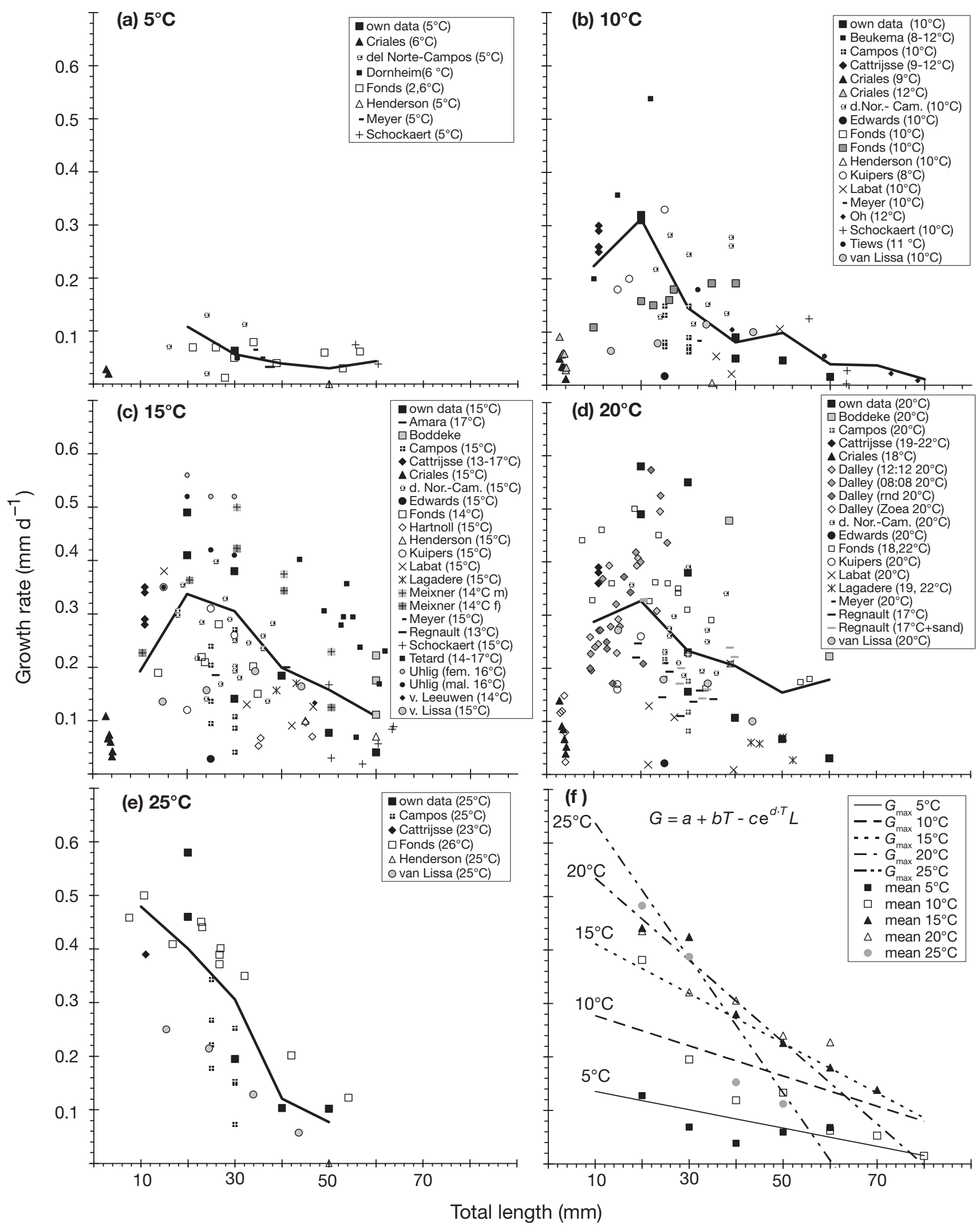

Fig. 1. Crangon crangon. Growth rates obtained from literature review and own data observed in the laboratory plotted according to length and temperature: (a-e) $5,10,15,20,25^{\circ} \mathrm{C}$; and (f) results obtained by quantile regression. Points: 75 th percentile of all North Sea studies; lines: model fitted to all data (Eq. 12) 
Fig. 2. Crangon crangon. Growth model $\left(G=a+b \cdot T-c \cdot \mathrm{e}^{d \cdot T} \cdot L\right)$ sensitivity analysis for the influence of single studies. From top to bottom: parameters $a$ to $d$. Dots: parameter estimates, and whiskers: confidence limits. For each study, 4 dots are shown: the leftmost describes the estimate when only the indicated study is taken out of the dataset, whereas the rightmost dots indicate the parameter estimates if 3 other randomly chosen studies are also left out

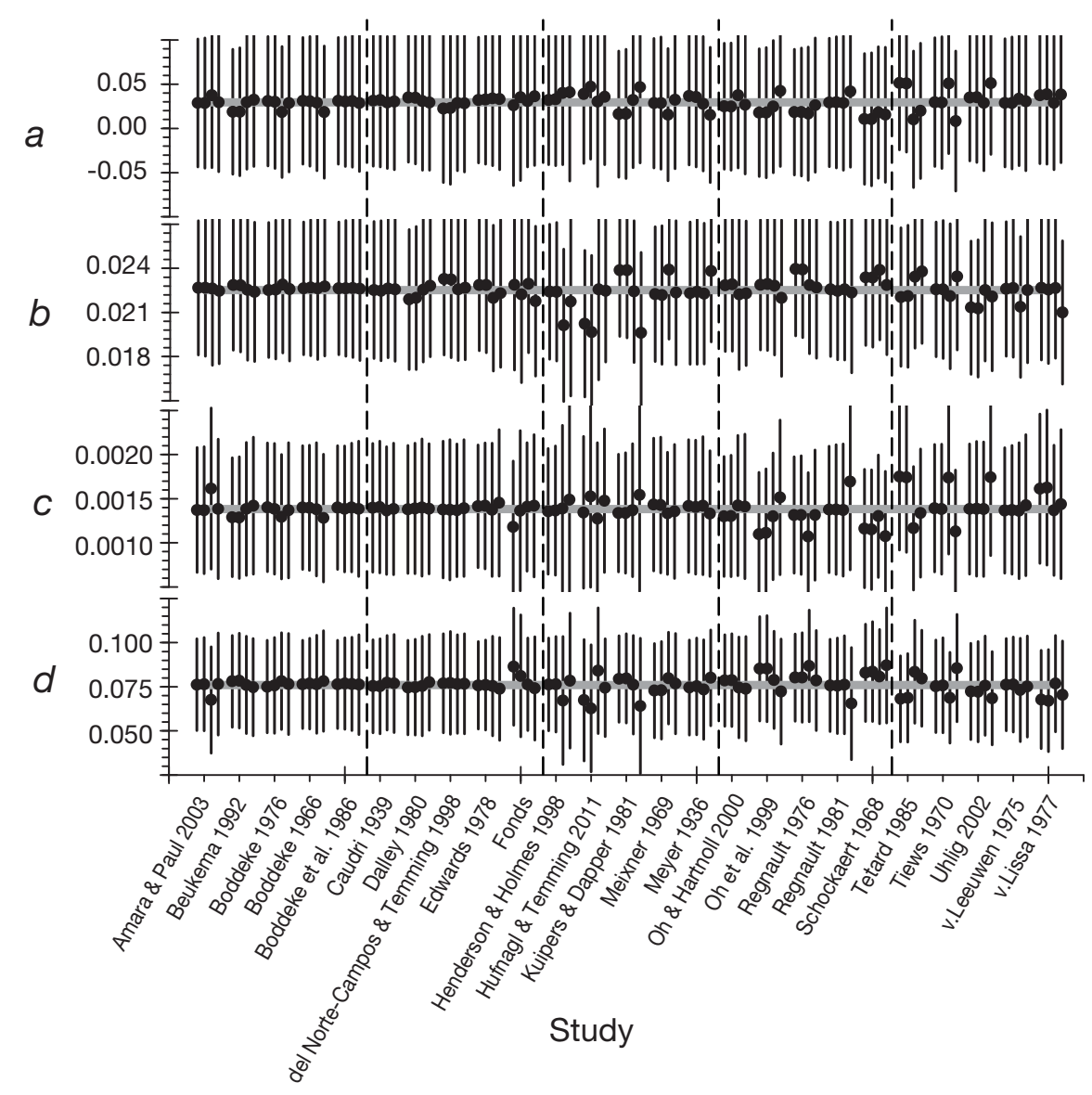

$$
\begin{aligned}
G_{\max }= & 0.03054( \pm 0.0040) \cdot T \\
& -0.00104( \pm 0.0005) \cdot \mathrm{e}^{0.09984( \pm 0.0106) \cdot T} \cdot L
\end{aligned}
$$

All 25 North Sea studies were included in parameterizing the growth model since none of the studies influenced the parameter estimates significantly. The CIs for parameter a in Eq. (5) always included zero and was therefore omitted. Eq. (5) was fitted without this parameter. All remaining parameters were significantly $(\mathrm{p}<$ 0.01) different from zero. Both growth models (with and without the temperature interaction term) explained a high degree of variability within the data. A lower $\mathrm{r}^{2}$ was calculated with temperature not acting on metabolism (Eq. 9; $\left.\mathrm{r}^{2}=0.74\right)$ than with interaction (Eq. 10; $\mathrm{r}^{2}=$ $0.87)$.

$$
\begin{aligned}
G= & 0.197( \pm 0.057)+0.011( \pm 0.002) \cdot T \\
& -0.00435( \pm 0.0009) \cdot L \\
G= & 0.02421( \pm 0.0021) \cdot T \\
& -0.00115( \pm 0.0004) \cdot \mathrm{e}^{0.08492( \pm 0.0144) \cdot T} \cdot L
\end{aligned}
$$

Parameters obtained either from a fit to the mean growth rates $+1 \mathrm{SD}$ (Eq. 11, $\mathrm{r}^{2}=0.85$ ), or by quantile regression (75th percentile Eq. 12, $\mathrm{r}^{2}=0.83$ ), were comparable.

$$
\begin{aligned}
G_{\text {mean }+ \text { SD }}= & 0.03453( \pm 0.0042) \cdot T \\
& -0.00121( \pm 0.0005) \cdot \mathrm{e}^{0.10004( \pm 0.0144) \cdot T} \cdot L
\end{aligned}
$$

For both models, the parameter estimates of one model were included in the respective CIs of the other model. In the following analysis, only the parameters derived from quantile regression (Eq. 12) were used to describe fast growth.

Few North Sea studies (Meixner 1969, Oh et al. 1999, Uhlig 2002, Hufnagl \& Temming 2011) separated growth rates by gender. Application of quantile regression or estimation of all parameters of Eq. (5) for a gender specific growth model was not possible. Therefore, parameter $d$ from Eq. (10) was used and gender specific parameters $b$ and $c$ were determined by nonlinear regression. Eqs. (13) \& (14) represent mean male $\left(\mathrm{r}^{2}=0.67\right)$ and mean female $\left(\mathrm{r}^{2}=0.79\right)$ growth rates, respectively.

$$
\begin{aligned}
G_{0^{7}}= & 0.03424( \pm 0.0083) \cdot T \\
& -0.0020( \pm 0.001) \cdot \mathrm{e}^{0.08777( \pm 0.0144) \cdot T} \cdot L \\
G_{\emptyset}= & 0.04028( \pm 0.0077) \cdot T \\
& -0.00193( \pm 0.0009) \cdot \mathrm{e}^{0.08777( \pm 0.0144) \cdot T} \cdot L
\end{aligned}
$$

Male growth rates were on average $83 \%( \pm 0.024 \mathrm{SE}$, $\mathrm{r}^{2}=0.935$ ) of female growth rates (Fig. 3) based on 


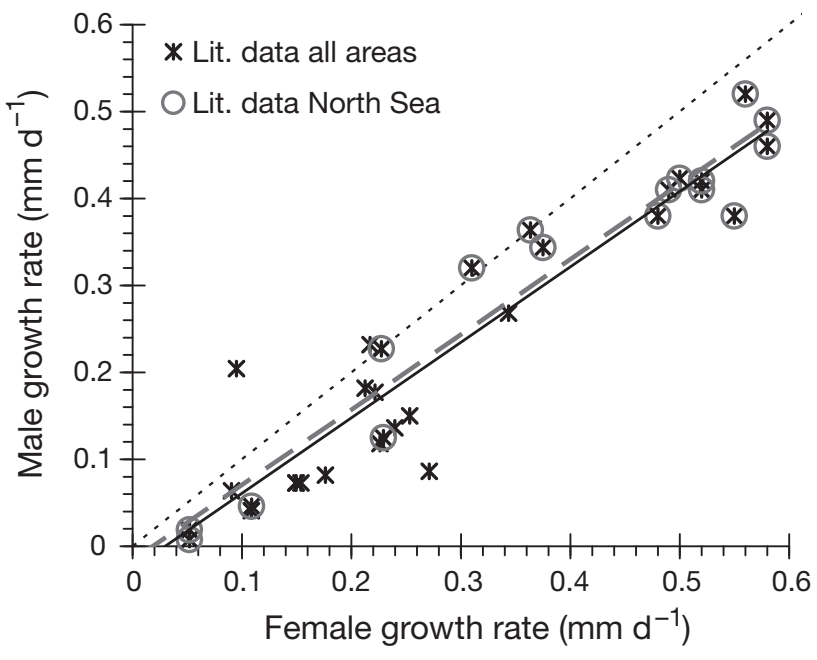

Fig. 3. Crangon crangon. Female and male growth rates $\left(\mathrm{mm} \mathrm{d}^{-1}\right)$. Dotted line: line of perfect (1:1) agreement

North Sea data from Meixner (1969), Oh et al. (1999), Uhlig (2002), and Hufnagl \& Temming (2011). If all studies reporting gender specific growth rates (previous references plus Labat 1977, Lagardère 1982, Campos et al. 2009b) were included, male growth rates would be $80.1 \%\left( \pm 0.028 \mathrm{SE}, \mathrm{r}^{2}=0.883\right)$ of female growth rates. For both data sets, intercepts were not significantly different from 0 and were therefore omitted.

The von Bertalanffy parameters $K, L_{\infty}$ and the growth performance index $\Phi^{\prime}$ were derived from Eqs. (9) to (14) (Table 3) based on the parameters determined for all growth models $\left(G, G_{\max }, G_{\text {mean }+\mathrm{SD}}, G_{O^{\prime}}, G_{\mathrm{O}^{7}}\right)$. We

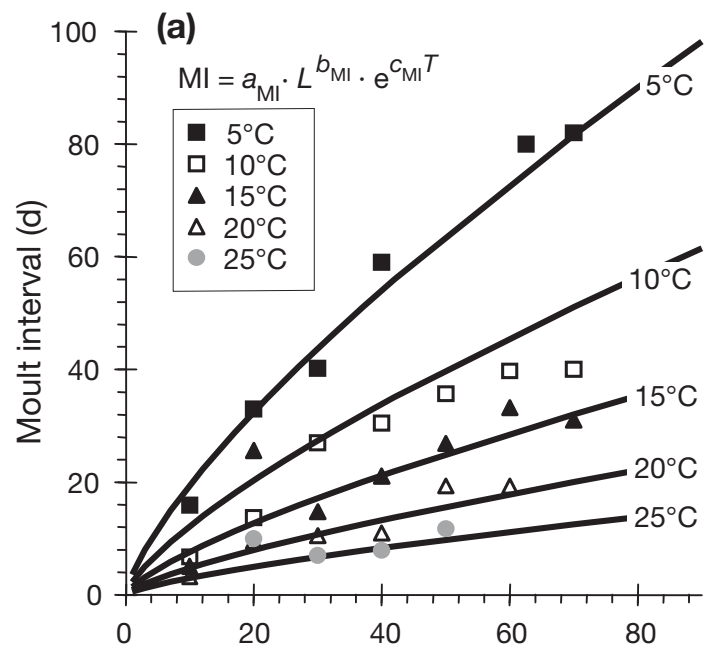

Table 3 . Von Bertalanffy growth parameters $K$ and $L_{\infty}$ growth performance index $\Phi^{\prime}$ and $Q_{10}$ for metabolism for mean and maximum, male and female growth models

\begin{tabular}{|lcccc|}
\hline & $K\left(10^{\circ} \mathrm{C}\right)$ & $L_{\infty}\left(10^{\circ} \mathrm{C}\right)$ & $\Phi^{\prime}$ & $Q_{10}$ \\
\hline$G$ no $T$ interaction & 1.59 & 70.57 & 3.90 & \\
$G$ plus $T$ interaction & 0.98 & 90.05 & 3.90 & 2.34 \\
$G_{\max }$ mean + SD & 1.20 & 104.94 & 4.12 & 2.72 \\
$G_{\max }$ 75th percentile & 1.03 & 108.20 & 4.08 & 2.71 \\
$G_{\text {q }}$ & 1.70 & 86.07 & 4.10 & 2.34 \\
$G_{0^{\prime \prime}}$ & 1.76 & 72.78 & 3.97 & 2.34 \\
\hline
\end{tabular}

assumed a mean annual North Sea temperature of $10^{\circ} \mathrm{C}$ (Eq. 7). Highest $\Phi^{\prime}$ of 4.08 to 4.12 were determined for $G_{\max }, G_{\phi}$ and $G_{\text {mean+SD }}$. Values for $G$ and $G_{O^{\prime \prime}}$ ranged from 3.90 to 3.97 .

\section{Moult interval and increment}

Fitting Eq. (8) to the moult interval data obtained from previously determined experimental data (Hufnagl \& Temming 2011) and literature values (Table 1) led to

$$
\begin{gathered}
\mathrm{MI}=5.7066( \pm 3.0514) \cdot L^{0.7364( \pm 0.1326)} \cdot \mathrm{e}^{0.09363( \pm 0.01237) \cdot T} \\
\left(\mathrm{r}^{2}=0.954\right)
\end{gathered}
$$

with all parameters being significantly different from zero $(\mathrm{p}<0.01)$. The theoretical maximum moult increment, which was calculated as the product of $G_{\max }$ and MI (Eq. 15), was greatest for Crangon crangon of $L=$ 30-40 mm (Fig. 4). Maximum increments of $6 \mathrm{~mm}$

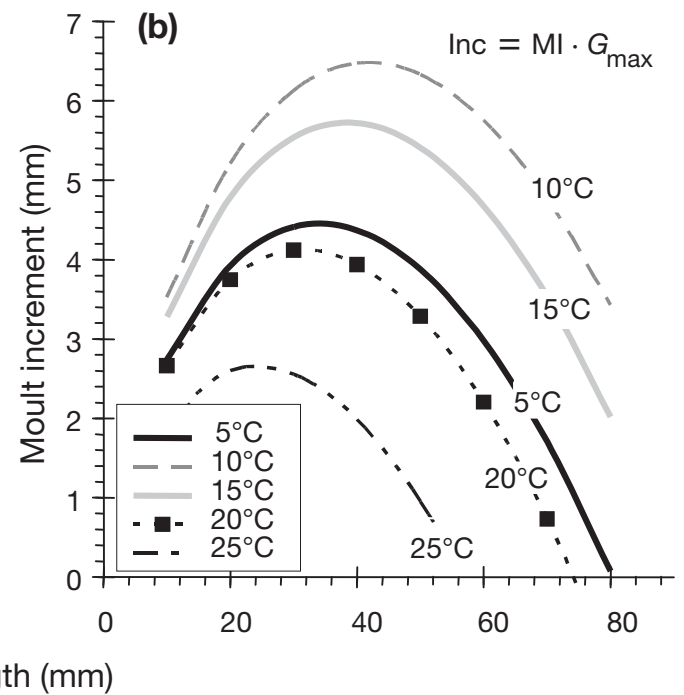

Fig. 4. Crangon crangon. (a) Mean moult intervals (MI; points) and Eq. (8) (lines) fitted to the data. (b) Theoretical moult increment (Inc) calculated as the product of the moult interval (Eq. 8) and the maximum growth (75th percentile quantile regression, Eq. 12) 

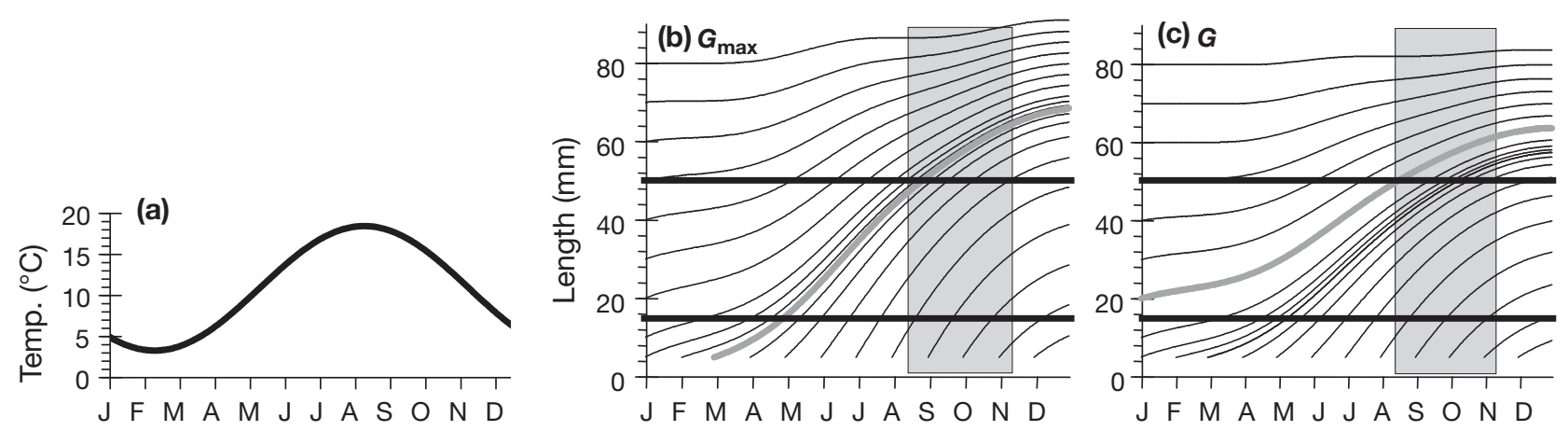

Fig. 5. Crangon crangon. Calculated length trajectories based on parameters derived for the different subsets and including water temperature (a) of the shallow North Sea at Weser light ship and Büsum. In all scenarios, animals start at $5 \mathrm{~mm}$ on each 1 st day of the month. Length trajectories were calculated using (b) maximum growth (75th percentile quantile regression, $G_{\max }$ ), and (c) mean growth $(G)$. Horizontal lines: length at recruitment $(15 \mathrm{~mm})$ and minimum catch length $(50 \mathrm{~mm})$. Grey curve: first cohort reaching $50 \mathrm{~mm}$ in September. Grey boxes: autumn/winter fishing season

were calculated for $40 \mathrm{~mm}$ shrimps at $10^{\circ} \mathrm{C}$, whereas smallest moult increments of $0-2 \mathrm{~mm}$ were predicted for a $T$ of $25^{\circ} \mathrm{C}$.

\section{Application of the model}

Applying seasonal North Sea temperatures (Fig. 5a, Eq. 7), most simulated shrimps recruiting at $5 \mathrm{~mm}$ in January to April reached $50 \mathrm{~mm}$ before September (Fig. $5 \mathrm{~b}$ ) when $G_{\max }$ was used. However, if trajectories were calculated using $G$ (the model representing mean

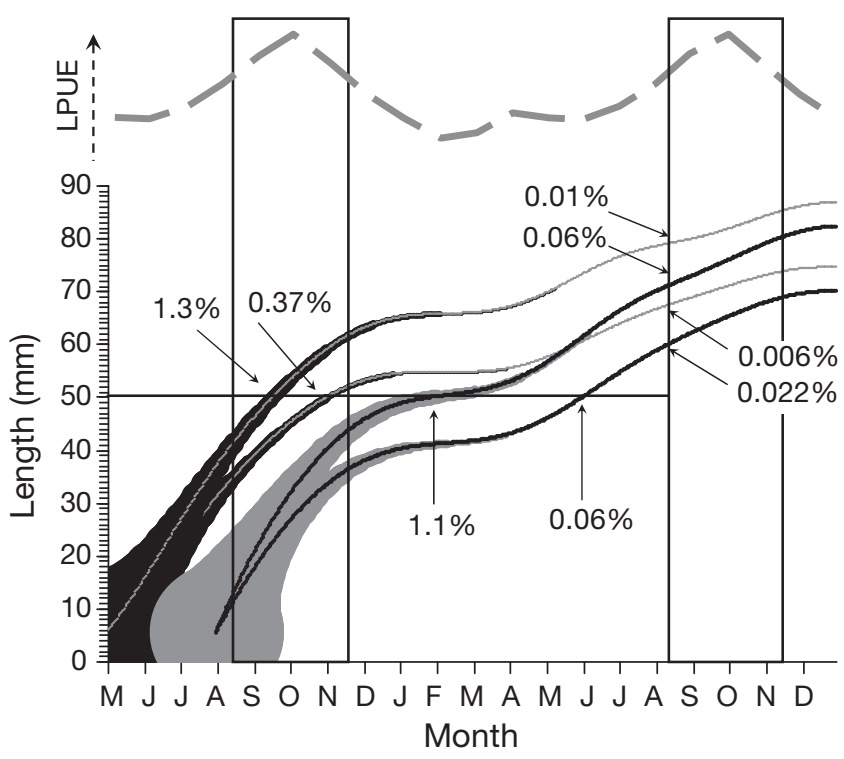

Fig. 6. Crangon crangon. Abundance and length. Comparison of May (winter egg hatched, black) and August (summer egg hatched, gray) juveniles assuming intermediate (lower lines) and fast growth (upper lines). Percentages indicate the fraction of shrimps left from initial cohort size upon reaching $50 \mathrm{~mm}$ or the period of high landings per unit effort (LPUE, Sep-Nov) growth, Fig. 5c), the $50 \mathrm{~mm}$ limit was reached 1 to $2 \mathrm{mo}$ later.

Using $G_{0^{t}}$ (the model representing mean male shrimp growth), length trajectories were below those using $G_{\max }$. Female length trajectories, which were calculated with $G_{\text {op }}$, were comparable to $G_{\max }$ trajectories.

The LPUE maximum (Fig. 6 top; ICES 2010) observed between September and November represents shrimps $>50 \mathrm{~mm}$. Both cohorts from the previous winter egg production and the previous year's summer egg production contribute to this adult biomass maximum (Fig. 6). However, the numerical importance of these components is controlled by the interaction between growth rates and cumulative mortality. For a typical fast growing $\left(G_{\max }\right)$ winter egg cohort starting at $5 \mathrm{~mm}$ in May, $1.3 \%$ of the initial number reach $50 \mathrm{~mm}$ in September of the same year. However, if average growth $(G)$ is assumed, the fraction attaining $50 \mathrm{~mm}$ is reduced to only $0.37 \%$ and this $50 \mathrm{~mm}$ size is not reached before November. The same calculation for a typical fast growing summer egg cohort starting at $5 \mathrm{~mm}$ in August allows $1.1 \%$ to reach commercial size in February. Of these shrimps, only $0.06 \%$ contribute to adult biomass in September of the following year. With average growth, $0.06 \%$ reach $50 \mathrm{~mm}$ in June and $0.022 \%$ contribute to the adult biomass maximum in September of the following year.

\section{DISCUSSION}

\section{Meta-analysis of growth data}

High variability in growth was observed both within and between all studies analyzed. However, despite the scatter, general patterns can be derived: (1) small animals grow faster than large ones; (2) the $L$ effect 
increases with increasing $T_{i}$ and (3) high variability was observed in all $T-L$ categories.

The negative effect of $L$ on growth and of $T$ on the slope (growth vs. $L$ ) can be interpreted in the context of the von Bertalanffy growth theory (von Bertalanffy 1934). The food-related term (anabolism) was expanded in our study with a linear $T$ term following Kuipers \& Dapper (1981). In addition, the catabolic term was expanded with an exponential $T$ effect. With rising temperatures, the catabolic term increasingly approaches the anabolic term, resulting in decelerated growth especially for large shrimps. This means that at a certain point, the animal is unable to channel enough energy to further growth, and all energy gained is channeled into maintenance or reproductive processes. The same mechanism could also have been modeled with a growth function with 2 exponential temperature terms, for both anabolism and catabolism, but with a smaller exponential coefficient on the anabolic term.

The intersection of the growth function (Eq. 5; Fig. 1f) with the $x$-axis represents $L_{\infty}$ (asymptotic length), which is the equilibrium length of anabolism and catabolism. At constant temperatures, maximum $L$ of $61 \mathrm{~mm}$ at $25^{\circ} \mathrm{C}$ and $108 \mathrm{~mm}$ at $10^{\circ} \mathrm{C}$ were predicted. This corresponds to field observations where populations dwelling at higher latitudes or in deeper water were found to reach larger sizes than related species in tropical regions (Gunter 1950, Angilletta et al. 2004).

\section{Factors influencing growth}

The parameter $b$, which mainly determines the intercept of Eq. (5) with the $y$-axis, is $40 \%$ higher for female $(b=0.040)$ than for male shrimps $(b=0.035)$. This translates into female growth rates being $~ 15 \%$ higher than male growth rates. A direct regression of male and female growth rates for comparable $L$ and $T$ classes indicated that male growth rates were 17 to $20 \%$ lower than female rates. The effect of gender on growth was discussed in more detail by Hufnagl et al. (2010a) and Hufnagl \& Temming (2011). Reproductive investment of female crustaceans increases with $L$, whereas searching ability and agility of male crustaceans decrease with $L$ (Bauer 2006). In pure-searching species where males display no guarding behavior, females reach larger sizes than males (Correa \& Thiel 2003) and display higher growth rates.

$T$ dependence, which is represented by parameter $d$ in the growth model for all scenarios $\left(G, G_{\max }, G_{\sigma^{\prime}}\right.$ and $G_{\phi}$ ), varied between 0.0849 and 0.100. Parameter $d$ can be converted into a $Q_{10}$ value according to $Q_{10}=\left(\frac{\mathrm{e}^{d \cdot T_{1}}}{\mathrm{e}^{d \cdot T_{2}}}\right)^{\frac{10}{T_{1}-T_{2}}}$. Crangon crangon $Q_{10}$ values range from 2.34 to 2.72 , being comparable to values for other ectotherms (reviewed by Angilletta et al. 2004; lower quartile 1.1, upper quartile 2.8) and lower than values determined for Crangon septemspinosa $\left(Q_{10}\right.$ between 2.85 and 3.01; Taylor \& Peck 2004).

Von Bertalanffy growth parameters $K, L_{\infty}$ and growth performance index $\Phi^{\prime}$ were comparable to previous findings for Crangon crangon. $L_{\infty}$ and $K$ values as determined by Tiews (1954), Tiews \& Schumacher (1982), and Kuipers \& Dapper (1984), respectively, ranged between $K=0.7,1.12$ and $0.95 ; L_{\infty}=110,85$ and 78 ; and $\Phi^{\prime}=3.93,3.91$ and 3.76. Applying the Powell (1979) and Wetherall et al. (1987) methods to lengthfrequency distributions of several long-term survey data, Hufnagl et al. (2010b) determined $L_{\infty}=79.3 \mathrm{~mm}$, assuming $K=1.17$, corresponding to $\Phi^{\prime}=3.87$.

The $T$ dependence of $K$ is comparable to rates determined in starvation experiments (Hufnagl et al. 2010c), increasing exponentially from $K=1.08$ at $9^{\circ} \mathrm{C}$ to $K=$ 2.29 at $20^{\circ} \mathrm{C}$. Brown shrimp growth performance indices determined in this study are high in comparison to other similar sized crustaceans like Farfantepenaeus californiensis $\left(\Phi^{\prime}=2.85-3.06\right.$; López-Martínez et al. 2003), Neocallichirus mirim $\left(\Phi^{\prime}=2.79-2.84\right)$, and Callichirus major $\left(\Phi^{\prime}=2.28-2.32\right.$; Botter-Carvalho et al. 2007). The higher value determined for brown shrimp, in comparison to the named species, indicates a higher growth performance and might indicate a shorter life span.

Although $T$ and $L$ explained most of the observed growth variability, unexplained variation still remains. This might originate from several sources, but here we will focus on (1) bias in the cohort tracking data; (2) bias related to laboratory experiments or factors such as food and habitat; (3) gender-specific growth rates in studies without sex differentiation; and (4) effects of pre-feeding history or genetic variability.

\section{(1) Cohort tracking}

Crangon crangon spawns throughout the year except in late autumn (Kuipers \& Dapper 1984, Neudecker \& Damm 1992). Permanent recruitment leads to a mixing of slow-growing individuals from early cohorts with fast-growing individuals from later cohorts. This makes it impossible to follow the length modes of individual cohorts over prolonged periods. Furthermore, small individuals are observed in shallow water, whereas larger animals prefer deeper water and tidal gullies. Gradual disappearance of shrimps $>20 \mathrm{~mm}$ (Beukema 1992) requires simultaneous sampling on the tidal flats and in deeper water. Since migration patterns are not only determined by $L$ but are also related to age, gender, season and $T$ (Boddeke 
1976, Boddeke et al. 1976, Pihl \& Rosenberg 1982, Spaargaren 2000), obtaining representative length compositions for the entire population is a difficult task requiring a large sampling effort.

In practical applications, growth rates of juveniles are most reliable because growth is fast and youngest cohorts are less affected by site dependent emigration into deeper water (del Norte-Campos \& Temming 1998, Amara \& Paul 2003). Cohort tracking of larger shrimp will only generate reliable growth estimates if a single recruitment event dominates in a local region and both emigration and immigration are unlikely to occur. Such a situation was analyzed on the northeast coast of France (Manche-est) by Tetard (1985) and their estimated growth rates are close to $G_{\max }$.

\section{(2) Laboratory artifacts}

Laboratory studies avoid many of the problems discussed for cohort tracking but generate other issues related to, e.g. prey composition, density or water quality. For Crangon crangon, especially food, group vs. individual rearing, health, noise and toxicity were examined.

Crangon crangon is an opportunistic omnivore (Pihl \& Rosenberg 1984, Boddeke et al. 1986, Feller 2006). Feeding experiments indicated a significant food type effect, with live copepods being the optimal diet (Hufnagl \& Temming 2011). Similar results were obtained in the laboratory when plankton or Artemia salina was provided as food (Meixner 1969, Dalley 1980, Uhlig 2002), whereas growth rates were lower when only $C$. crangon (Edwards 1978) or nematodes (Gerlach \& Schrage 1969) were used. Uhlig (2002) observed that frozen smelt supports only slow growth of C. crangon (20 $\mathrm{mm} \mathrm{L:} 0.25 \mathrm{~mm} \mathrm{~d}^{-1}$ ), whereas fresh caught, live plankton doubled the growth rates of shrimps $(20 \mathrm{~mm}$ $L: 0.56 \mathrm{~mm} \mathrm{~d}^{-1}$ ). The food type therefore seems to be important for high growth to occur.

The high densities of animals in laboratory vessels in comparison to those in the field might influence growth rates by creating stress. This induces higher energy consumption for activity, resulting in less energy available for growth. Onnen \& Zebe (1982) described that tail flipping, a common escape mechanism in Crangon crangon, as very cost intensive. For Penaeus esculentus, feeding and walking increased oxygen consumption by $45 \%$ and active swimming by $130 \%$ (Blaxter \& Southward 1991). Lower growth rates might therefore be a result of higher activity and metabolic costs.

Regnault $(1970,1976)$ observed that Crangon septemspinosa grew faster when isolated than when in groups, or when held on natural substrate than without substrate. Stress therefore influences growth and growth variability, while shelter (sand) might compensate for stress or reduce activity. In Regnault's experiments, total length of isolated shrimps increased from 8 to $32 \mathrm{~mm}$ and that of grouped shrimp only from 8 to $18 \mathrm{~mm}$. Contrary to Regnault's findings, high growth rates with group setups were observed by Hufnagl \& Temming (2011), M. Fonds (unpubl.), and Uhlig (2002).

Tiews (1970) reported that animals with missing extremities grew slower over successive moults due to the added costs of limb regeneration. If animals do not get optimum food, aggressive interactions (leading to cannibalism) may increase, causing more injuries and therefore slowing growth rates. The regeneration effect could also partially explain the observed variability in laboratory experiments. Catching, treatment or shell diseases could also lead to injuries of shrimps, which then grow slower than their healthy conspecifics.

In summary, optimum conditions would be obtained by rearing small groups at low densities within tanks having natural substrate like sand or small gravel, and using a mixture of prey optimally including natural live zooplankton.

\section{(3) Gender}

Growth of female Crangon crangon in our analysis was $\sim 15$ to $20 \%$ higher than that of males. The differences in growth observed between genders could explain part of the growth variability reported in studies with mixed genders of shrimp. However, even in experiments where gender was registered and rearing conditions were close to the perceived optimum for this species, growth variation still existed. For example, females $(20 \mathrm{~mm} L)$ reared in the same tank grew at minimum and maximum rates of 0.4 and $0.75 \mathrm{~mm} \mathrm{~d}^{-1}$, respectively (Hufnagl \& Temming 2011).

(4) Effects of pre-feeding history or genetic variability

Working with Penaeus monodon, Benzie (1997) reported that $10 \%$ of the growth variability in the progeny was determined by genetic factors. A similar study has not been conducted for Crangon crangon, hence no statement about maternal or paternal effects on growth can be made.

Several authors observed that genetic variability in the field is low and only differs between very remote places (Bulnheim \& Schwenzer 1993, Beaumont \& Croucher 2006, Luttikhuizen et al. 2008), which might lead to latitudinal differences in growth performance (Campos et al. 2009a). All studies analyzed and used 
for the parameterization here were from the North Sea region where no genetic differences have been observed (Luttikhuizen et al. 2008). The high inter- and intrastudy variability (Fig. 1) might therefore eventually be explained not by regional genetic effects but by differences in individual genetic growth potentials.

\section{Moult interval and increment}

Maximum moult increments were deduced indirectly by multiplying estimates of $G_{\max }$ and moult interval. Based on this calculation, maximum increments of $7 \mathrm{~mm}$ for a $40 \mathrm{~mm}$ shrimp were obtained. These values are comparable to values observed by Meixner (1969) and Hufnagl \& Temming (2011). Translating these increments into wet weight (Eq. 1) would result in a maximum weight gain of $50 \%$ for $40 \mathrm{~mm}$ shrimps at $10^{\circ} \mathrm{C}$ and $100 \%$ for $20 \mathrm{~mm}$ shrimps at the same temperature. These values seem high but it should be taken into account that weight growth does not take place during the moult event but is a gradual process over the whole intermoult period. Due to the hard exoskeleton, weight growth is achieved by reduction of the water content and steady replacement of water with protein (Rosa \& Nunes 2004). The observed increment is therefore only achieved by an uptake of water and subsequent expansion. Therefore, the 50 to $100 \%$ growth has to be distributed over the whole moult interval, reducing these values to a net wet weight growth rate of 1.5 and $4 \% \mathrm{~d}^{-1}$, respectively. This is within the range of values for other crustaceans (e.g. blue crab: 1.5 to $9.3 \% \mathrm{~d}^{-1}$; Rice \& Short 1989) and lower than rates observed for larval fish of comparable size (e.g. menhaden, fork length: $28-55 \mathrm{~mm}$, mean $\pm \mathrm{SD}$ growth: $9 \pm 7 \% \mathrm{~d}^{-1}$; Hettler 1976)

Approximately $95 \%$ of the observed variability was explained by $T$ and $L$ if Eq. (8) was fitted to $T$ and $L$ binned mean moult intervals. This indicates that feeding and habitat conditions influence moult intervals only to a minor extent and that moulting follows more regular, perhaps hormone controlled, patterns. Reasons are most probably maturation processes or avoidance of shell diseases and parasites as discussed by Buchholz et al. (2006) for krill.

\section{Application of the growth model}

Growth trajectories based on mean growth rates and ambient temperatures suggest that $15 \mathrm{~mm}$ shrimps in May and July do not reach $50 \mathrm{~mm}$ prior to October. While these shrimps represent the main recruitment peak that is observed each year in the shallow intertidal areas of the Wadden Sea (Temming \& Damm
2002), the predicted growth rates are insufficient to explain the peak of commercial catches in September (see Fig. 6; ICES 2010). However, the match with the catch peak is much closer if maximum growth $\left(G_{\max }\right)$ from quantile regression (75th percentile) or female growth is used for the predictions. This is in contrast to the growth hypothesis of Campos et al. (2009a) who assumed that the autumn landings maximum is connected to the previous year's summer recruitment. Due to high mortality rates, only a very small fraction of shrimps is actually left after $1 \mathrm{yr}$, hence it is unlikely that the recruitment of the previous summer augments the adult maximum in autumn of the current year.

High mortality rates are related to the high numbers of potential brown shrimp predators. Predators of adult shrimps are mainly cod and whiting (Daan 1973, Singh-Renton \& Bromley 1999) and grey gurnard in deeper water (de Gee \& Kikkert 1993). For juvenile shrimps, besides cannibalistic conspecifics (Regnault 1976, Evans 1984, Pihl \& Rosenberg 1984), the gobiid Pomatoschistus sp., flatfish such as Pleuronectes platessa, Platichthys flesus, Limanda limanda, Hippoglassoides platessoides, and Solea solea, and other species such as Agonus cataphractus, and Ciliata mustela (Braber \& de Groot 1973, Evans 1984, Jansen 2002) need to be included.

The current year summer eggs, which Boddeke \& Becker (1979) identified as the main recruitment source, are also only contributing to a small extent to the autumn landings maximum of the same year. Assuming egg development times similar to the moult interval (Eq. 8) of $\sim 30 \mathrm{~d}$ at summer temperatures of 10 to $15^{\circ} \mathrm{C}$ and $L=55 \mathrm{~mm}$, larval developmental times according to Criales \& Anger (1986) of an additional $30 \mathrm{~d}$ (between 10 and $15^{\circ} \mathrm{C}$ ), and a summer egg period of mid April to mid September, larvae hatched from the first summer eggs will reach $5 \mathrm{~mm}$ in mid June. According to Fig. 5, only fast growing juveniles hatched from the earliest summer eggs (hatched in April, recruiting in June) of the present year will reach adult length between October and November, towards the end of the autumn catch peak.

According to the calculations shown in Figs. 5 \& 6 , the abundance of shrimps growing at $G_{\max }$ and reaching commercial length is $4 \times$ higher than that of shrimps growing only at $G$ due to higher cumulative mortality in the latter. Shrimps starting at $5 \mathrm{~mm}$ total length between January and June and growing at $G_{\max }$ reach commercial length between September and November, whereas shrimps growing at $G$ need 1 to 3 mo longer (Fig. 5). It can therefore be concluded that the fast growing shrimps are of vital importance for the autumn harvest and also for the population as they will carry the winter eggs from which the new cohort emerges. 
The existence of high growth rates in nature is also supported by the results of the only field study where distinct cohorts of large shrimps were analyzed to have growth rates comparable to $G_{\max }$ (Tetard 1985). Tetard (1985) sampled brown shrimps within a rather enclosed estuary where a single distinct spawning event happened, allowing the tracking of a single cohort over a longer time span without mixing effects.

The better fit of $G_{\max }$ (which is almost equal to $G_{\wp}$ ) with field observations in comparison to $G$ might be because the larger size classes are dominated by females (Tiews 1970, Martens \& Redant 1986, Hufnagl et al. 2010a). However, even when only considering females, growth variability is still high.

One aspect that has not been taken into account here is that juvenile shrimps $(<20 \mathrm{~mm})$ might experience higher temperatures than assumed in the model. During low tide, when juvenile animals reside on tidal flats and in small pools (Berghahn 1983, 1991, Beukema 1992), growth might increase significantly due to warming, if sufficient food exists. A $5^{\circ} \mathrm{C}$ difference in ambient temperature experienced by shrimps $<20 \mathrm{~mm}$ would lead to commercial length being reached 2 to 3 wk earlier. However, this result would not influence the previous conclusions about the importance of the winter eggs but might increase the proportion of shrimps growing at $G$ that reach commercial length.

Based on the results of this study, the life cycle of Crangon crangon can be summarized as follows: the autumn peak in adult shrimp is dominated by females $>50 \mathrm{~mm}$. By winter, these shrimps have grown into the length class $>60 \mathrm{~mm}$. Within this length class, $>90 \%$ of the female shrimps carry eggs in winter (Oh et al. 1999, Siegel et al. 2008). These females subsequently spawn the eggs for the recruitment peak of juveniles of $\sim 15 \mathrm{~mm} L$, in the following May or June (Temming \& Damm 2002). Approximately $1.3 \%$ of these juveniles grow into the adult length class within summer and reach commercial length (>50 $\mathrm{mm}$ ) in September, assuming $G_{\max }$. Approximately $0.37 \%$ of the shrimps growing at $G$ (mean growth rate) reach adult length 1 mo later. Thus, the life cycle and the population is dominated by an annual cycle: hatch from winter eggs, recruitment into the shallow Wadden Sea areas in late spring, maximum growth during summer, marketable length in autumn and production of winter eggs.

These findings indicate that the summer recruitment is less important despite summer egg production being much higher (Temming \& Damm 2002) than winter egg production. Temming \& Damm (2002) calculated an egg production index based on the assumption that eggs are released after each moult. Due to the short moult intervals during summer, this assumption strongly influences their summer egg production estimate. Klęk-Kawińska \& Bomirski (1975) assumed only
2 ovipositions during summer, which at least halves the abundance of the previous summer eggs. Further studies focusing on oviposition, gonad development and fertilization processes are therefore recommended to gain a better insight into summer and winter egg production rates.

If the egg production rates that we assumed here are correct, another explanation for the high summer egg peak could be that the life cycle might be different in other areas. Crangon crangon covers a large distribution area including the Black, Mediterranean, North and Baltic Seas as well as the Atlantic, whereas the present study mainly focused on the southern North Sea. Kuipers \& Dapper (1984) reviewed latitudinal trends in spawning seasons and the work of Campos et al. (2009b) also indicates that latitudinal trends in growth performance might exist. However, gene flow within the North Sea is not hindered and no subpopulations were identified (Luttikhuizen et al. 2008). Hence, one adaptation mechanism for different temperature and feeding situations could be variability in growth and production. In more northern areas, production of summer eggs might be the most efficient strategy.

The demonstrated relevance of the winter egg production also implies that increased mortality of adult shrimps during winter might affect the commercial recruitment of Crangon crangon. The recently observed increase in the winter fishery, which is driven by high prices during this time, could theoretically reduce the spawning stock size. Such effects might presently be masked by the historically low level of key brown shrimp predators: cod and whiting preying on the adult stock in late autumn and winter (Welleman \& Daan 2001). Recovery of the stock size of these predators in combination with increased winter fishing on egg-carrying females might negatively impact the brown shrimp population.

Future research should focus on the causes of the high individual growth variability observed in laboratory studies. The application of condition and growth proxies (e.g. RNA/DNA ratio) or the instantaneous growth rate method (Hart 2001) could reveal the extent of this variability under field conditions.

Acknowledgements. The study was financially supported by the Federal Ministry of Food, Agriculture and Consumer Protection, Germany, Project No. 03HS030. We thank the reviewers for their work, helpful comments and suggestions.

\section{LITERATURE CITED}

Amara R, Paul C (2003) Seasonal pattern in the fish and epibenthic crustaceans community of an intertidal zone with particular reference to the population dynamics of plaice and brown shrimp. Estuar Coast Shelf Sci 56: 807-818 
Angilletta MJJ, Steury TD, Sears MW (2004) Temperature, growth rate, and body size in ectotherms: fitting pieces of a life-history puzzle. Integr Comp Biol 44:498-509

Bauer RT (2006) Same sexual system but variable sociobiology: evolution of protandric simultaneous hermaphroditism in Lysmata shrimps. Integr Comp Biol 46:430-438

Beaumont AR, Croucher T (2006) Limited stock structure in UK populations of the brown shrimp, Crangon crangon, identified by morphology and genetics. J Mar Biol Assoc UK 86:1107-1112

Benzie JAH (1997) A review of the effect of genetics and environment on the maturation and larval quality of the giant tiger prawn Penaeus monodon. Aquaculture 155:69-85

Berghahn R (1983) Untersuchungen an Plattfischen und Nordseegarnelen (Crangon crangon) im Eulitoral des Wattenmeeres nach dem Übergang zum Bodenleben. Helgol Meersunters 36:163-181

Berghahn R (1991) Winterfischerei Ja oder Nein? Einige biologische Grundlagen für die Beurteilung dieser Frage sowie erste Untersuchungsergebnisse. Fischerblatt 6: $173-180$

Beukema JJ (1992) Dynamics of juvenile shrimp Crangon crangon in a tidal-flat nursery of the Wadden Sea after mild and cold winters. Mar Ecol Prog Ser 83:157-165

Blaxter JHS, Southward AJ (1991) Moulting and growth. Adv Mar Biol 27:213-250

Boddeke R (1966) Sexual cycle and growth of brown shrimp (Crangon crangon). ICES Shellfish Committee CM 1966/ M:6

> Boddeke R (1976) The seasonal migration of the brown shrimp Crangon crangon. Neth J Sea Res 10:103-130

Boddeke R (1982) The occurrence of winter and summer eggs in the brown shrimp (Crangon crangon) and the pattern of recruitment. Neth J Sea Res 16:151-162

Boddeke R, Becker HB (1979) A quantitative study of the stock of brown shrimp (Crangon crangon) along the coast of the Netherlands. Rapp P-V Réun Cons Int Explor Mer 175:253-258

Boddeke R, Dijkema R, Stemelink ME (1976) The patterned migration of shrimp populations: a complete study of Crangon crangon and Penaeus brasiliensis. FAO fisheries report. Symp Proc Mar Biol Carribean Corsas 200:31-49

Boddeke R, Driessen G, Doesburg W, Ramaekers G (1986) Food availability and predator presence in a coastal nursery area of the brown shrimp (Crangon crangon). Ophelia 26:77-90

Botter-Carvalho ML, Santos PJP, Carvalho PVVC (2007) Population dynamics of Callichirus major (Say, 1818) (Crustacea, Thalassinidea) on a beach in northeastern Brazil. Estuar Coast Shelf Sci 71:508-516

Braber L, de Groot SJ (1973) The food of five flatfish species (Pleuronectiformes) in the southern North Sea. Neth J Sea Res 6:163-172

Buchholz CM, Buchholz F, Tarling GA (2006) On the timing of moulting processes in reproductively active northern krill Meganyctiphanes norvegica. Mar Biol 149:1443-1452

Bulnheim HP, Schwenzer DE (1993) Zur Populationsgenetik von Crangon crangon und C. allmanni (Crustacea, Decapoda) im Bereich der europäischen Küsten. Zool Jahrb Abt Allg Zool Physiol Tiere 97:327-347

Campos J, van der Veer HW, Freitas V, Kooijman SALM (2009a) Contribution of different generations of the brown shrimp Crangon crangon (L.) in the Dutch Wadden Sea to commercial fisheries: a dynamic energy budget approach. J Sea Res 62:106-113

> Campos J, Freitas V, Pedrosa C, Guillot R, van der Veer HW (2009b) Latitudinal variation in growth of Crangon cran- gon (L.): Does counter-gradient growth compensation occur? J Sea Res 62:229-237

Cattrijsse A, Dankwa HR, Mees J (1997) Nursery function of an estuarine tidal marsh for the brown shrimp Crangon crangon. J Sea Res 38:109-121

Caudri LWD (1939) Einfluss der Temperatur und des Salzgehalts auf die Sterblichkeit von Garnelen (Crangon crangon L.). Arch Neerl Zool 3:179-196

Correa C, Thiel M (2003) Mating systems in caridean shrimp (Decapoda: Caridea) and their evolutionary consequences for sexual dimorphism and reproductive biology. Rev Chil Hist Nat 76:187-203

- Criales MM, Anger K (1986) Experimental studies on the larval development of the shrimps Crangon crangon and $C$. allmanni. Helgol Meersunters 40:241-265

> Daan N (1973) A quantitative analysis of the food intake of North Sea cod, Gadus morhua. Neth J Sea Res 6:479-517

Dalley R (1980) The survival and development of the shrimp Crangon crangon (L.), reared in the laboratory under noncircadian light-dark cycles. J Exp Mar Biol Ecol 47: $101-112$

de Gee A, Kikkert AH (1993) Analysis of the grey gurnard (Eutrigla gurnardus) samples collected during the 1991 International Stomach Sampling Project. ICES Demersal Fish Committee CM 1993/G:14

del Norte-Campos AGC, Temming A (1998) Population dynamics of the brown shrimp Crangon crangon L., in shallow areas of the German Wadden Sea. Fish Manag Ecol 5:303-322

Dornheim H (1969) Beiträge zur Biologie der Garnele Crangon crangon (L.) in der Kieler Bucht. Ber Dtsch Wiss Komm Meeresforsch 20:179-215

Edwards RRC (1978) Effects of water-soluble oil fractions on metabolism, growth and carbon budget in the shrimp Crangon crangon. Mar Biol 46:259-265

Evans S (1984) Energy budgets and predation impact of dominant epibenthic carnivores on a shallow soft bottom community at the Swedish west coast. Estuar Coast Shelf Sci 18:651-672

Feller RJ (2006) Weak meiofaunal trophic linkages in Crangon crangon and Carcinus maenas. J Exp Mar Biol Ecol 330:274-283

Gerlach SA, Schrage M (1969) Freilebende Nematoden als Nahrung der Sandgarnele Crangon crangon. Oecologia 2: $362-375$

Gunter G (1950) Correlation between temperature of water and size of marine fishes on the Atlantic and Gulf coast of the United States. Copeia 4:298-304

Gurney AR (1982) The larval development of Crangon crangon (Fabr. 1795) (Crustacea: Decapoda). Bull Br Mus (Nat Hist) Zool 42:247-262

Hart RC (2001) Rapid estimation of in situ growth rates of Caridina nilotica (Crustacea: Decapoda) in Lake Victoria: description and pilot application of a simple, field-compatible technique. Limnol Oceanogr 46:692-698

> Hartnoll R (2001) Growth in Crustacea - twenty years on. Hydrobiologia 449:111-122

Havinga B (1930) Der Granat (Crangon vulgaris, Fabr.) in den holländischen Gewässern. J Cons Int Explor Mer 5:57-87

Henderson PA, Holmes RHA (1987) On the population biology of the common shrimp Crangon crangon (L.) (Crustacea: Caridea) in the Severn Estuary and Bristol Channel. J Mar Biol Assoc UK 67:825-847

> Henderson PA, Seaby RMH, Somes JR (2006) A 25-year study of climatic and density-dependent population regulation of common shrimp Crangon crangon (Crustacea: Caridea) in the Bristol Channel. J Mar Biol Assoc UK 86:287-298 
Hettler WF (1976) Influence of temperature and salinity on routine metabolic rate and growth of young Atlantic menhaden. J Fish Biol 8:55-65

Hufnagl M, Temming A (2011) Growth in the brown shrimp Crangon crangon. I. Effects of food, temperature, size and gender, moulting, and cohort. Mar Ecol Prog Ser 435: 141-154

Hufnagl M, Temming A, Dänhardt A (2010a) Hermaphroditism in brown shrimp: lessons from field data and modelling. Mar Biol 157:2097-2108

Hufnagl M, Temming A, Siegel V, Tulp I, Bolle L (2010b) Estimating total mortality and asymptotic length of Crangon crangon (Linnaeus, 1758) between 1955 and 2006. ICES J Mar Sci 67:875-884

Hufnagl M, Temming A, Dänhardt A, Perger R (2010c) Is Crangon crangon (L. 1758, Decapoda, Caridea) food limited in the Wadden Sea? J Sea Res 64:386-400

ICES (2010) Report of the Working Group on Crangon fisheries and life history. ICES Living Resources Committee, CM 2009/LRC:07

Jansen S (2002) Das Räuber-Beutesystem juveniler Gadiden, Grundeln und Garnelen im Wattenmeer nördlich von Sylt. $\mathrm{PhD}$ dissertation, University of Hamburg

Klęk-Kawińska E, Bomirski A (1975) Ovary-inhibiting hormone activity in shrimp (Crangon crangon) eyestalks during the annual reproductive cycle. Gen Comp Endocrinol 25:9-13

Koenker R, Bassett G (1978) Regression quantiles. Econometrica 46:33-50

Kuipers BR, Dapper R (1981) Production of Crangon crangon in the tidal zone of the Dutch Wadden Sea. Neth J Sea Res 15:33-53

Kuipers BR, Dapper R (1984) Nursery function of Wadden Sea tidal flats for the brown shrimp Crangon crangon. Mar Ecol Prog Ser 17:171-181

Labat JP (1977) Écologie de Crangon crangon (L.) (Decapoda, Caridea) dans un étang de la côte languedocienne. Vie Milieu XXVII:273-292

> Lagardère JP (1982) Effects of noise on growth and reproduction of Crangon crangon in rearing tanks. Mar Biol 71: $177-185$

Lloyd AJ, Yonge CM (1947) The biology of Crangon vulgaris L. in the Bristol Channel and Severn Estuary. J Mar Biol Assoc UK 26:626-661

López-Martínez J, Arreguin-Sánchez F, Hernández-Vázquez S, García-Juárez AR, Valenzuela-Quiñonez W (2003) Interannual variation of growth of the brown shrimp Farfantepenaeus californiensis and its relation to temperature. Fish Res 61:95-105

Luttikhuizen PC, Campos J, van Bleijswijk J, Peijnenburg KTCA, van der Veer HW (2008) Phylogeography of the common shrimp, Crangon crangon (L.) across its distribution range. Mol Phylogenet Evol 46:1015-1030

Maes J, Taillieu A, Van Damme PA, Cottenie K, Ollevier F (1998) Seasonal patterns in the fish and crustacean community of a turbid temperate estuary (Zeeschelde Estuary, Belgium). Estuar Coast Shelf Sci 47:143-151

Martens E, Redant F (1986) Protandric hermaphroditism in the brown shrimp Crangon crangon (L.), and its effects on recruitment and reproductive potential. ICES Shellfish Committee CM 1986/K:37

Meixner R (1969) Wachstum, Häutung und Fortpflanzung von Crangon crangon (L.) bei Einzelaufzucht. Ber Dtsch Wiss Komm Meeresforsch 20:93-111

Meyer PF (1936) Die Nordseekrabbe (Granat, Garnele) Crangon vulgaris Fabr. im Jadebusen. Z Fischerei 34:319-358

Munro JL, Pauly D (1983) A simple method for comparing the growth of fishes and invertebrates. Fishbyte 1:5-6

Neudecker T, Damm U (1992) Seasonality of egg-bearing shrimp (Crangon crangon L.) in coastal waters of the German Bight. ICES Shell Fish Committee K 28:1-9.

Oh CW, Hartnoll RG (2000) Effects of food supply on the growth and survival of the common shrimp Crangon crangon (Linnaeus, 1758) (Decapoda, Caridea). Crustaceana 73:83-99

Oh CW, Hartnoll R, Nash RDM (1999) Population dynamics of the common shrimp, Crangon crangon (L.), in Port Erin Bay, Isle of Man, Irish Sea. ICES J Mar Sci 56:718-733

Onnen T, Zebe E (1982) Energy metabolism in the tail muscles of the shrimp Crangon crangon during work and subsequent recovery. Comp Biochem Physiol A 74:833-838

Paschke KA, Gebauer P, Buchholz F, Anger K (2004) Seasonal variation in starvation resistance of early larval North Sea shrimp Crangon crangon (Decapoda: Crangonidae). Mar Ecol Prog Ser 279:183-191

Peterson I, Wroblewski JS (1984) Mortality rate of fishes in the pelagic ecosystem. Can J Fish Aquat Sci 41:1117-1120

Pihl L, Rosenberg R (1982) Production, abundance, and biomass of mobile epibenthic marine fauna in shallow waters, western Sweden. J Exp Mar Biol Ecol 57:273-301

Pihl L, Rosenberg R (1984) Food selection and consumption of the shrimp Crangon crangon in some shallow marine areas in western Sweden. Mar Ecol Prog Ser 15:159-168

Powell DG (1979) Estimation of mortality and growth parameters from the length frequency of a catch. Rapp P-V Réun Cons Int Explor Mer 175:167-169

Regnault M (1970) Croissance au laboratoire de Crangon septemspinosa Say (Crustacea, Decapoda, Natantia), de la métamorphose à la maturité sexuelle. Bull Mus Natl Hist Nat 2e Sér 42:1108-1126

Regnault M (1976) Influence du substrat sur la mortalité et la croissance de la crevette Crangon crangon (L.) en élevage. Cah Biol Mar XVII:347-357

Regnault M (1979) Ammonia excretion of the sand-shrimp Crangon crangon (L.) during the moult cycle. J Comp Physiol 133:199-204

Regnault M (1981) Respiration and ammonia excretion of the shrimp Crangon crangon L.: metabolic response to prolonged starvation. J Comp Physiol 141:549-555

Rice SD, Short JW (1989) Uptake and catabolism of tributyltin by blue crabs fed TBT contaminated prey. Mar Environ Res 27:137-145

Rosa R, Nunes ML (2004) RNA, DNA and protein concentrations and amino acid profiles of deep-sea decapod Aristeus antennatus: an indication for seasonal variations of nutrition and growth. Aquat Living Resour 17:25-30

Salz P, de Wilde JW (1990) De Rol van de Garnalenvisserij voor de Nederlandse Kottervloot. Landbouw-Economisch Instituut, Den Haag

Schatte J, Saborowski R (2005) Change of external sexual characteristics during consecutive moults in Crangon crangon L. Helgol Mar Res 60:70-73

Schockaert E (1968) La croissance de la crevette grise (Crangon crangon L.) au large de la cote Belge. Ann Soc R Zool Belg 98:217-231

Siegel V, Damm U, Neudecker T (2008) Sex-ratio, seasonality and long-term variation in maturation and spawning of the brown shrimp Crangon crangon (L.) in the German Bight (North Sea). Helgol Mar Res 62:339-349

Singh-Renton S, Bromley PJ (1999) Feeding of small whiting (Merlangius merlangus) in the central and southern North Sea. J Mar Biol Assoc UK 79:957-960

- Spaargaren DH (2000) Seasonal and annual variations in the catches of Crangon crangon (L. 1758) (Decapoda, Natan- 
tia) near the coast of Texel, the Netherlands. Crustaceana 73:547-563

Taylor DL, Peck MA (2004) Daily energy requirements and trophic positioning of the sand shrimp Crangon septemspinosa. Mar Biol 145:167-177

Temming A, Damm U (2002) Life cycle of Crangon crangon in the North Sea: a simulation of the timing of recruitment as a function of the seasonal temperature signal. Fish Oceanogr 11:45-58

Tetard A (1985) Elements sur la croissance de la crevette grise, Crangon crangon (L.), en Manche-est et sud Mer du Nord. ICES CM 1985/K:17

Tiews K (1954) Die biologischen Grundlagen der Büsumer Garnelenfischerei. Ber Dtsch Wiss Komm Meeresforsch 13:235-269

Tiews K (1970) Synopsis of biological data on the common shrimp Crangon crangon (Linaeus, 1758). FAO Fish Rep 4: 1167-1223

Tiews K, Schumacher A (1982) Assessment of brown shrimp stocks (Crangon crangon L.) off the German coast for the period 1965-1978. Arch Fischwiss 32:1-11

Uhlig N (2002) Wachstum und Ernährungssituation der Nordseegarnele Crangon crangon (L.). MSc thesis, University of Hamburg

van Leeuwen F (1975) Verspreiding van verschillende garna- lensoorten in de Zuidelijke Noordzee gedurende verschillende seizoenen. Interne Verslagen Nederlands Instituut voor Onderzoek der Zee, Texel 8:1-23

van Lissa JHL (1977) Aantallen, voedselopname, groei en produktie van de garnaal (Crangon crangon L.) in een getijdengebied, alsmede de voedselopname en groei onder laboratoriumomstandigheden. Interne Verslagen Nederlands Instituut voor Onderzoek der Zee, Texel 1977 C:1-100

Viegas I, Martinho F, Neto J, Pardal M (2007) Population dynamics, distribution and secondary production of the brown shrimp Crangon crangon (L.) in a southern European estuary. Latitudinal variations. Sci Mar 71:451-460

von Bertalanffy L (1934) Untersuchungen über die Gesetzlichkeit des Wachstums I. Teil: Allgemeine Grundlagen der Theorie; Mathematische und Physiologische Gesetzlichkeiten des Wachstums bei Wassertieren. Dev Genes Evol 131:613-651

Welleman HC, Daan N (2001) Is the Dutch shrimp fishery sustainable? Senckenbergia Marit 31:321-328

Wetherall JA, Polovina JJ, Ralston S (1987) Estimating growth and mortality in steady-state fish stocks from length frequency data. In: Pauly D, Morgan GR (eds) Length-based methods in fishery research. 13th ICLARM Conf Proc, Manila, p 53-74

Submitted: October 11, 2010; Accepted: May 31, 2011

Proofs received from author(s): July 22, 2011
Editorial responsibility: Konstantinos Stergiou, Thessaloniki, Greece 